\title{
Political Climate and Catastrophes: The EfFects of Notorious Events on PubliC Library COllections, BOTH THEN AND Now
}

\author{
JOSEPH A. CUSTER ${ }^{*}$
}

\section{INTRODUCTION}

The early 1950s in the United States was a period of considerable sensitivity to Communist influence. ${ }^{1}$ One area of sensitivity was the patron collections in public libraries. ${ }^{2}$ Challenges regarding what people could read during this period came from self-proclaimed, ultra-patriotic censors like the American Legion, Daughters of the American Revolution (DAR), Sons of the Revolution (SAR), and the Chamber of Commerce. ${ }^{3}$

Stoking the fear of Communist subversion and the resulting anxieties of American citizens were the sensational and hyperbolic charges made by Senator Joseph McCarthy. The Senator spoke of removing Communist books from public libraries in $1950 .^{4}$ Libraries became targets as ostensible repositories and distributors of Communist propaganda. ${ }^{5}$ Many times, the protests centered on the supposed use of Communist reading materials to indoctrinate schoolchildren. ${ }^{6} \mathrm{~A}$ running theme through this paper is evil forces attempting to indoctrinate our

* Associate Professor of Law and Director, Judge Ben C. Green Law Library. Author's Note: I want to thank an excellent former faculty fellow Daniel Rankin, now an associate at Preg O'Donnell \& Gillett in Seattle, Washington, for his excellent research of articles, books, the Internet, etc., for early 1950s censorship examples, saying nothing of his vast research into additional time periods creating fodder for future time period papers. I also want to thank Case Western Reserve University School of Law Professor Andrew Pollis who took the time to read and provide excellent advice and guidance for the paper. Heidi Kuehl, Director of the Law Library and Associate Professor of Law, also provided valuable insight. In addition, Reference Librarian SaraJean Petite did outstanding work on checking reference citations and correctly formatting.

1. Larry Ceplair, Anti-Communism in Twentieth-Century America: A Critical HISTORY 91 (2011).

2. Wayne A. Wiegand, Main Street Public Library: The Availability of Controversial Materials in the Rural Heartland, 1890-1956, 33 LiBr. \& Culture 127, 130 (1998).

3. Christine Jenkins, International Harmony: Threat or Menace? U.S. Youth Services Librarians and Cold War Censorship, 1946-1955, 36 LiBR. \& CULTURE 116, 118 (2001).

4. James B. ConAnt, My Several Lives: Memoirs of A Social InVEntor 566-69 (1970).

5. Geoffrey R. Stone, Free Speech in the Age of McCarthy: A Cautionary Tale, 93 CAL. L. REV. 1387, 1396 (2005).

6. Milton S. Gwirtzman, Post Joins McCarthy Crusade, HARv. Crimson (Oct. 27, 1953), https://www.thecrimson.com/article/1953/10/27/post-joins-mccarthy-crusade-pa-student/ [https://perma.cc/8PYF-JW4A] (“On September 27, 1952, the [Boston] Post's eight-column banner headlined KREMLIN NEWSPAPERS IN HUB LIBRARY READING ROOM. . . . The article told how Communists could lure children to the papers [in the library] and fill their ears with translated propaganda. This story was part of the [ultra-conservative] Post's effort to remove Russianlanguage newspapers from the Boston Public Library."). 
children with dangerous propaganda. ${ }^{7}$ President Donald Trump, at his 2020 Fourth of July celebration at Mount Rushmore, stated: "Against every law of society and nature, our children are taught in school to hate their own country and to believe that the men and women who built it were not heroes but that they were villains."

The dangers of the indoctrination of schoolchildren by progressives had an earlier appearance in the Trump administration. Trump nominated Sam Clovis for the top scientist at the United States Department of Agriculture. ${ }^{9}$ Clovis, in an earlier period, was a conservative talk radio host. ${ }^{10}$ In 2011 , he wrote that progressives who "have advanced several 'isms' that tend to warp and twist the logic and intellectual development of children" hold over $70 \%$ of America's children through the public education system captive. ${ }^{11}$ Clovis ended up withdrawing his name for consideration, not because of pressure over the statements about progressives indoctrinating schoolchildren, but because it came out that he was an ally of George Papadopoulos. ${ }^{12}$ Papadopoulos is "the Trump campaign aide who pleaded guilty in October to lying to the FBI about his contact with Russia ...."

The Nazis were also worried about Jews and Judaism indoctrinating their youth. The introduction of the "Jewish question"14 befell schoolchildren at an early age. ${ }^{15}$ Classes and textbooks taught anti-Semitism primarily through the advocacy of race theory. ${ }^{16}$ The Nazis were also proponents of teaching storybook

7. See generally supra text accompanying note 6; see generally infra text accompanying notes $8,10,154,199,333$.

8. Alexandra Hutzler, Trump Blames Schools for Statue Protesters, Says Children Taught to 'Hate Their Own Country', NewsweEK (July 4, 2020, 11:41 AM), https://www.newsweek.com/ trump-blames-schools-statue-protesters-says-children-taught-hate-their-own-country-1515425 [https://perma.cc/TT6L-ZLGD].

9. Sam Clovis, WIKIPEDIA, https://en.wikipedia.org/wiki/Sam_Clovis (last visited Oct. 28, 2020) [https://perma.cc/ALS6-4WXJ].

10. Andrew Kaczynski, Trump Pick Sam Clovis Blasted Schools for 'Indoctrinating'Students with Ideas like 'Environmentalism' and 'Racism', CNN (Nov. 2, 2017, 11:50 AM), https://www.cnn.com/2017/11/01/politics/kfile-sam-clovis-newsletters/index.html [https://perma.cc/44SY-NTQM].

11. Id.

12. Joe Sobczyk, Trump USDA Nominee Withdraws After Link to Russia Probe, BloOMBERG (Nov. 2, 2017, 11:14 AM), https://www.bloomberg.com/news/articles/2017-11-02/trump-nomineeclovis-withdraws-after-link-to-russia-probe [https://perma.cc/B8HZ-VG7J].

13. Kaczynski, supra note 10.

14. Jewish Question, WiKIPEDIA, https://en.wikipedia.org/wiki/Jewish_Question (last visited Oct. 27, 2020) [https://perma.cc/5S8M-QGH4].

15. Mary Mills, Poisoning Young Minds in Nazi Germany: Children and Propaganda in the Third Reich, 66 Soc. EDUC. 228 (2002), http://www.socialstudies.org/sites/default/files/ publications/se/6604/660407.shtml [https://perma.cc/5UMH-QTQR].

16. Id. 
propaganda in school. ${ }^{17}$ The most prevalent of the storybook authors was Julius Streicher. ${ }^{18}$ Streicher was a German soldier in World War I and a schoolteacher. ${ }^{19}$ He lost his teaching position in 1923 because he participated in the attempted violent overthrow of Germany. ${ }^{20}$ The propaganda storybooks were placed in evidence at the Nuremberg Trials to demonstrate the laying of the groundwork for the Final Solution. ${ }^{21}$ Streicher was sentenced to death at Nuremberg. ${ }^{22}$

This paper explores four different cases in the early 1950s of "Red Scare" tactics that influenced the freedoms that patrons using public libraries have enjoyed. ${ }^{23}$ The paper will also examine, at various points, the censorship parallels in the early 1950 s to the contemporary political climate and the fallout of the Great Depression to the current catastrophe, COVID-19. The paper reviews the fallout from the Great Depression and how the world's depression helped catapult Adolph Hitler of Germany to power. ${ }^{24}$ Hitler severely restricted or eliminated freedoms of expression, and the Trump administration's actions reflect some of those same restrictions. ${ }^{25}$

One early 1950s case involved the dismissal of a public librarian in Bartlesville, Oklahoma. Ruth Brown, the small city's chief librarian, was accused of circulating so-called subversive materials. ${ }^{26}$ The mentioned subversive materials were the public front hiding the racist biases of the Bartlesville leaders. ${ }^{27}$ The small city not only viewed the librarian as a Communist sympathizer but also an advocate for the rights of African Americans. ${ }^{28}$ In the Jim Crow South, social and political change were as welcome as the Oklahoma scorpion, and forces in Bartlesville's small city were not ready to concede to any enlightenment. ${ }^{29}$ The case went all the way to the Supreme Court of Oklahoma,

17. Id.

18. Id.

19. Id.

20. Id.

21. $I d$.

22. $I d$.

23. Red Scare, WIKIPEDIA, https://en.wikipedia.org/wiki/Red_Scare (last visited Oct. 27, 2020) [https://perma.cc/7MTG-GD3H] ("A 'Red Scare' is the promotion of a widespread fear of a potential rise of communism or anarchism by a society or state.").

24. U.S. Holocaust Mem'1 Museum, Hitler Comes to Power, Holocaust EnCyClopedia, https:/encyclopedia.ushmm.org/content/en/article/hitler-comes-to-power (last visited Oct. 27, 2020) [https://perma.cc/BV32-NJVE].

25. Jeff Nesbit, History Repeats: Propaganda and the Destruction of the Free Press, U.S. NEws (Oct. 26, 2017), https://www.usnews.com/news/at-the-edge/articles/2017-10-26/trumppropaganda-and-the-destruction-of-the-free-press [https://perma.cc/C6DE-S9MR].

26. Louise S. Robbins, The Dismissal of Miss Ruth Brown: Civil Rights, Censorship, AND the American Library 3 (2000) [hereinafter Robbins, Dismissal of Miss Ruth Brown].

27. $I d$.

28. Id.

29. Id. at 18 ("Although Bartlesville's Chamber of Commerce touted its parks, theaters, schools, and other cultural and national benefits as ingredients that made the town 'America's ideal 
as addressed below. ${ }^{30}$

The second case, involving the Boston Public Library collection, transpired in 1952 and made front-page news. Izvestia and Pravda, Soviet periodicals, were among the available serials in the Hub Library Reading Room. ${ }^{31}$ A picture of an assistant librarian holding copies of the two periodicals was on the front page of the Boston Post. ${ }^{32}$ The headline title read, "Kremlin Newspapers in Hub Library Reading Room," with the subtitle reading, "Soviet Data Is Available to Readers of All Ages." "33 The coverage deplored the Library's collection of Soviet Communist "propaganda" in a reading room near where young people studied. ${ }^{34}$ Some library employees, speaking to the newspaper anonymously, were terrified of possible youth corruption. ${ }^{35}$ The news story captured the city's attention and soon led to the Mayor's Office, as discussed below. ${ }^{36}$

In case three, San Antonio's mayor also interfered with its public library's collections. ${ }^{37} \mathrm{He}$ contended that works like Albert Einstein's Theory of Relativity and Herman Melville's Moby Dick (with illustrations by Communist Rockwell Kent) belonged on a list of books to be branded with red warning stamps identifying them as "Communist-written volumes." ${ }^{38}$ The city manager went further, suggesting the burning of the books. ${ }^{39}$

The fourth case involves Senator Joseph McCarthy who, in 1953, focused on supposed Communist infiltration of the United States Department of State's information centers, its Voice of America broadcasts, and its overseas libraries. ${ }^{40}$ His chief counsel, Roy Cohn, and chief consultant, David Schine, made a breakneck tour of American libraries in Europe and returned with a list of Communist writers found in their collections. ${ }^{41}$ American public library leaders

family center,' African Americans could not take advantage of these benefits. Most parks, movie theaters, restaurants, and hotels were closed to them, and their school was outfitted with leftovers from Bartlesville's white schools."); The BugGuy, The Deadliest Insects and Bugs in Oklahoma, Bug GuY Pest Control (July 11, 2018), https://thebugguyokc.com/2018/07/11/deadliest-insectsbugs-oklahoma/ [https://perma.cc/W4ZD-EAN2] (Scorpions are among the "deadliest insects and bugs in Oklahoma.").

30. See State ex rel. Brown v. Dunnaway, 248 P.2d 232 (Okla. 1952).

31. Kremlin Newspapers in Hub Library Reading Room, Bos. Post, Sept. 27, 1952, at 1 [hereinafter Kremlin Newspapers].

32. Id.

33. Id.

34. Hynes Would Have Labels, Bos. Post, Sept. 27, 1952, at 3.

35. Id.

36. Boston Board Keeps Red Books in Library, N.Y. Times, Oct. 4, 1952, at 24.

37. Richard B. Henderson, Maury Maverick: A Political Biography 286 (2010).

38. Id.

39. San Antonio Public Library Book Censorship, SAn Antonio Remembers (Mar. 22, 2009), http://sanantonioremembers.blogspot.com/2009/03/san-antonio-public-library-book.html [https://perma.cc/G6QU-FUHF].

40. Milly S. Barranger, Margaret Webster: A Life in the Theater 243 (2004).

41. Id. 
expressed great concern, fearing that McCarthy would eventually place his next sights on domestic public libraries. ${ }^{42}$

During the height of the Red Scare, in 1953, Ray Bradbury wrote in his classic, Fahrenheit 451, "There is more than one way to burn a book. And the world is full of people running about with lit matches." ${ }^{43}$ One of those who seemed to be running around with lit matches is the Trump Administration. Trump's targets for censorship are several. He has censored many scientists in government agencies. ${ }^{44}$ His administration censored climate studies. ${ }^{45}$ The President suggested on October 5, 2017, that the Senate Intel Committee should explore censoring the press. ${ }^{46}$

One of President Trump's censorship targets was China-based messaging apps TikTok and WeChat. ${ }^{47}$ The type of heavy-handed censorship effort at the network level, blocking communications from network servers to all people in the United States, is extremely complicated, not to mention legally dubious. ${ }^{48}$ Nevertheless unfazed, the President issued two executive orders on August 6, 2020, against the apps, citing national security concerns. ${ }^{49}$ The principal reason stated for the orders is the potential danger of the apps sharing data about United States citizens with the Chinese government. ${ }^{50}$

42. Louise S. Robbins, The Overseas Libraries Controversy and the Freedom to Read: U.S. Librarians and Publishers Confront Joseph McCarthy, 36 LiBr. \& Culture 27, 30 (2001) [hereinafter Robbins, Overseas Libraries Controversy].

43. RAy BradBury, FAHrenheit 451, at 176 (Ballantine Books 1991) (1953).

44. Jacob Carter, Gretchen Goldman \& Charise Johnson, Science Under Trump: Voices of Scientists Across 16 Federal Agencies, Union of Concerned Scientists (Aug. 2018), https://www.ucsusa.org/sites/default/files/images/2018/08/science-under-trump-report.pdf [https://perma.cc/V6LM-B48S].

45. Helena Bottemiller Evich, Agriculture Department Buries Studies Showing Dangers of Climate Change, PoLITICO, https://www.politico.com/story/2019/06/23/agriculture-departmentclimate-change-1376413 (last updated June 23, 2019, 10:37 PM) [https://perma.cc/SDF2-967D].

46. David A. Graham, Trump Wants to Censor the Media, Atlantic (Oct. 5, 2017), https:/www.theatlantic.com/politics/archive/2017/10/trump-wants-to-censor-the-press/542142/ [https://perma.cc/5G M3-23SA] (citing Donald J. Trump (@realDonaldTrump), TwITTER (Oct. 5, 2017, 6:59 AM), https://twitter.com/realDonaldTrump/status/915894251967385600 [https://perma. cc/CK8H-L8D2] ("Why Isn't the Senate Intel Committee looking into the Fake News Networks in OUR country to see why so much of our news is just made up-FAKE!")).

47. Adi Robertson, How the Trump Administration Could 'Ban' TikTok, Verge (Aug. 1, 2020, 12:12 AM) https://www.theverge.com/2020/7/9/21315983/trump-pompeo-ban-tiktokbytedance-chinese-social-media-national-security-censorship-methods [https://perma.cc/S8S2U6BJ].

48. Id.

49. Rachel Lerman, Trump Issues Executive Orders Against Chinese-owned TikTok and WeChat, Citing National Security Concerns, SeAtrle Times (Aug. 6, 2020, 8:57 PM), $\mathrm{https}$ //www.seattletimes.com/business/technology/trump-issues-executive-orders-against-chineseowned-tiktok-and-wechat-citing-national-security-concerns/ [https://perma.cc/L8QX-TYH6].

50. Id. 
As Justice Louis Brandeis stated in 1927, "Men feared witches and burnt women. It is the function of speech to free men from the bondage of irrational fears." 51 To combat fears that led men to burn women is to allow speech concerning witches and witch-hunting full and uncensored consideration.

\section{RUTH BROWN}

In 1950, the Citizen Committee, a self-designated commission in Bartlesville, Oklahoma, targeted the small city's public library for collecting such periodicals as the Nation, the New Republic, and Soviet Russia Today. ${ }^{52}$ A lesser-voiced target was a segregated YWCA supported by the public librarian. ${ }^{53}$ The Commission ran up against a determined YWCA Board of Directors that enjoyed near-unanimous membership support in resisting the Commission, defending the interracial program for "creating amicable and just race relationships based on mutual understanding and respect."

The Bartlesville Library Board supported librarian Ruth Brown, the chief librarian for thirty years, against the aggressive Commission. ${ }^{55}$ The Board met with the Citizen Committee at the Bartlesville Board of Commissioners' meeting on March 6, 1950. A near-riot broke out in a room of over 200 spectators. ${ }^{56}$ Robert Manuel, a Phillips Oil company engineer, challenged the committee members' experience to judge the library contents when none of them held a library card. ${ }^{57}$ Some of the crowd yelled names at engineer Manuel and demanded his removal from the meeting. ${ }^{58}$ Undaunted, Manuel continued until he was interrupted by the Mayor, who asked: "Who are you? What right have you to challenge this group of respected citizens? Are you a Commie?"59

The Vice-mayor, a Legionnaire, another ultra-patriotic organization, ${ }^{60}$ ended the meeting with a short sermon on the dangers of Communism. ${ }^{61} \mathrm{He}$ said that the library "should be a place where our youth will be thoroughly indoctrinated with the principles of Americanism, and where they will be protected from the

51. Whitney v. California, 274 U.S. 357, 376 (1927) (Brandeis, J., concurring).

52. Robbins, Dismissal of Miss Ruth Brown, supra note 26, at 56-60.

53. Id. at 61-67.

54. Oklahoma Library Association Committee on Intellectual Freedom, Censorship in Bartlesville, 45 ALA Bull., Mar. 1951, at 87, 87 [hereinafter Censorship in Bartlesville].

55. RobBins, Dismissal of Miss Ruth BRown, supra note 26, at 66-67.

56. Louise S. Robbins, Racism and Censorship in Cold War Oklahoma: The Case of Ruth W. Brown and the Bartlesville Public Library, 100 Sw. HIST. Q. 18, 29 (1996) [hereinafter Robbins, Racism and Censorship].

57. Id.

58. Id.

59. Id.

60. See Howard A. Ozmon, Jr., Better Dead than Well-Read?, 43 Phi Delta Kappan, Feb. 1962, at 222, 223.

61. Robbins, Racism and Censorship, supra note 56, at 29. 
teachings of subversive doctrines." ${ }^{62}$ As people left, the Board of Commissioners told the Library Board to make a full report on the library. ${ }^{63}$ Both the Library Board and Commission issued reports. ${ }^{64}$

The reports, printed in the May 28, 1950, Bartlesville Examiner-Enterprise ${ }^{65}$ stated two distinct positions. The Library Board's report stated in part:

It should be clearly understood that the Board's determination that any publication is suitable for inclusion in the City Library does not imply approval or advocacy of the views expressed in the book or periodical in question, either by the Board, or by its individual members. The Board believes that a policy of selection which would confine the Library's contents to materials consonant with the opinions of the Board or any of its members, or of any other citizen or group of citizens in the community, would be subversive of the basic principles which differentiate the constitutional government of the United States from the governments of authoritarian states. ${ }^{66}$

The Citizen Committee's report expressed a contrarian view, the character of which can be assessed with this excerpt:

These citizens are of the opinion that the presentation of contrasting points of view on controversial subjects does not require the surrender of our libraries to fifth column ${ }^{67}$ invasion. The freedom of the press has never been interpreted to tolerate the printing of counterfeit money. Counterfeit literature, designed to defame and destroy the heritage of American freedom, should be exposed instead of tolerated. ${ }^{68}$

The participants at the May 25 Commissioner's meeting discussed the Library Board's response. ${ }^{69}$ The library report included portions of the "Library Bill of Rights" and the American Library Association (ALA)'s official statement opposing censorship and upholding the freedom of inquiry. ${ }^{70}$ The Library Board was not aware that the report was on the agenda and was under-represented, while

62. $I d$.

63. Censorship in Bartlesville, supra note 54, at 88.

64. Id.

65. Id.

66. Id.

67. Merriam Webster defines "fifth column" as "a group of secret sympathizers or supporters of an enemy that engage in espionage or sabotage within defense lines or national borders," and the example in its October 1, 2008, "Word of the Day" feature said that "[i]n the 1950s the Communist Party was denounced in the United States as a fifth column, and many people were unjustly blacklisted as Communist sympathizers." Word of the Day: Fifth Column, Merriam-Webster (Oct. 1, 2008), https://www.merriam-webster.com/word-of-the-day/fifth\%20column-2008-10-01 [https://perma.cc/UUF3-KU39].

68. Censorship in Bartlesville, supra note 54, at 88.

69. Robbins, Racism and Censorship, supra note 56, at 33.

70. Id. at 32 . 
the Citizen Committee had been told it was on the agenda and they were well represented. $^{71}$ The Citizen Committee, using documents from the House Committee on Un-American Activities provided by the American Legion, analyzed the Bartlesville Public Library periodicals list. ${ }^{72}$

The Committee criticized various publications (e.g., the Nation touted the "the prattle of the Communists" and advertised "such subjects as sexology and homosexuality."). ${ }^{73}$ Library Board President Russell Davis read the Library Board's report, receiving no questions. ${ }^{74}$ The only comment offered after the reading of the Library Board's report was the mention of "An Ordinance Pertaining to the Control and Operation of the Bartlesville Public Library" to be effective on July $1,1950 .^{75}$

On June 14, 1950, the Board of Commissioners adopted a new public library ordinance. ${ }^{76}$ The new ordinance had an emergency clause stating that as soon as the ordinance was passed, approved, and published, it would go into effect on July 1, 1950, which it did..$^{77}$ The Bartlesville Examiner-Enterprise published the ordinance on June $16,1950 .^{78}$ The new ordinance stated that the Library Board and librarian could be removed at any time by the Board of Commissioners. ${ }^{79}$ The same body had the authority to appoint a new Library Board and librarian. ${ }^{80}$ All purchases of books and periodicals also had to meet the Library Board's approval, and the Board of Commissioners had to approve all library rules and regulations. $^{81}$

On July 10, 1950, the Commissioners under the new ordinance replaced the old library board with a new one ${ }^{82}$ The Commissioners unanimously selected Postmaster E.R. Christopher as the chair. ${ }^{83}$ Mr. Christopher was a Legionnaire like the Vice-mayor. ${ }^{84}$ The other members of the new library board included Dr. Elizabeth Chamberlin, a physician and longtime member of the DAR. ${ }^{85}$ Dr. Chamberlin was also a member of the same Episcopal Church that Ruth Brown attended, and she was resentful of Brown's inviting "Blacks" to church. ${ }^{86} \mathrm{Mrs}$. Lloyd Lynd, another appointed member, was active in Pro-America, a

71. Id. at 33 .

72. Id.

73. Id.

74. Id.

75. Id.

76. Censorship in Bartlesville, supra note 54, at 87-88.

77. Id.; see also Robbins, Racism and Censorship, supra note 56, at 33.

78. Censorship in Bartlesville, supra note 54, at 88.

79. Id.

80. Id.

81. Id.

82. $I d$.

83. Robbins, Racism and Censorship, supra note 56, at 33.

84. Id.

85. $I d$.

86. Id. at 34 . 
conservative women's group. ${ }^{87}$ The other new board member, Donald Koppel, was a self-proclaimed library neophyte who was surprised at being named to the Board. $^{88}$

Ruth Brown, distraught over the dismissal of the supportive library board, felt like resigning, but the strong support of her friends urged her to stay on ${ }^{89}$ The Mayor invited her to his office on July $25 .{ }^{90} \mathrm{He}$ asked many questions, such as whether she had ever signed the State of Oklahoma loyalty oath. ${ }^{91}$ Brown replied that she had not but would be willing to. ${ }^{92}$ Upon hearing her response, city manager E.E. Jones looked through his desk to find a copy of the oath to provide Brown but was unsuccessful. ${ }^{93}$

President Truman initiated the federal loyalty program in $1947,{ }^{94}$ and stateled anti-subversion laws continued to gain momentum well into the $1950 \mathrm{~s} .^{95} \mathrm{In}$ March of 1950, Elizabeth Haas, a librarian who served her country as a WAC ${ }^{96}$ in the Pacific Theatre of Operations and subsequently became a Quaker, was dismissed for her refusal to sign the loyalty oath required of all Maryland state employees. ${ }^{97}$ Haas stated,

"My objection is not based primarily upon the statement [the oath] itself, which contains nothing I could not affirm truthfully and without mental reservations. ... On both political and religious grounds [, however,] this law seems to me to be a positive evil and a denial of principles in which I believe most strongly."

87. Id.

88. Id.

89. Id.

90. Id.

91. Id.; see also Wieman v. Updegraff, 344 U.S. 183, 183 (1952) ("Oklahoma Stat. Ann., 1950, Tit. 51, $\S \S 37.1-37.8$ (1952 Supp.), requires each state officer and employee, as a condition of his employment, to take a 'loyalty oath,' stating, inter alia, that he is not, and has not been for the preceding five years, a member of any organization listed by the Attorney General of the United States as 'communist front' or 'subversive."').

92. See Minutes of the meeting held at the City Manager's office (July 25, 1950), in RuTH W. BROWN PAPERS, 1891-1976 (2018), https://digitalcommons.pittstate.edu/rwb/2 [https://perma. cc/254D-RPCJ] [hereinafter Minutes].

93. Id.

94. Louise S. Robbins, After Brave Words, Silence: American Librarianship Responds to Cold War Loyalty Programs, 1947-1957, 30 LiBr. \& Culture 345, 347 (1995) [hereinafter Robbins, After Brave Words, Silence].

95. Id. at 348 .

96. Acronym given to women who served in the Woman's Army Corps. Women's Army Corps: United States Army, Encyclopaedia Britannica (Jan. 21, 2020), https://www. britannica.com/topic/Womens-Army-Corps [https://perma.cc/CHS4-VJ55].

97. Loyalty Oath Dismissal, 44 ALA Bull., May 1950, at 149, 149.

98. Id. 
The Board of Governors of the Enoch Pratt Free Library, where Haas worked, issued the following statement:

"No one knowing her could ever doubt her forthright loyalty, or her faith in and adherence to the democratic way of life. . . . Her dismissal offers unhappy evidence of the Ober Act, designed to exclude Communists from public office, has instead eliminated an honest, able, patriotic citizen from an important community service. We are convinced this is a bad law and trust that, from this incident, the electorate, recognizing the injustices arising from it, will take appropriate action in the referendum of this fall." ${ }^{\prime 99}$

At its 1950 summer Cleveland conference, the ALA unanimously adopted a resolution recording its opposition to the Maryland Ober Law, a law requiring "candidates for appointive or elective office to certify whether they are members of 'subversive' organizations." 100 The Council said in its resolution: "we believe it to be a definite threat to the constitutional rights of librarians since it permits their discharge on the principle of guilt by association in lieu of direct evidence of subversion, and we support the Maryland Library Association in its efforts to have the law repealed." 101

Librarian Brown was not enjoying the same compassion and support librarian Haas experienced while working in the Enoch Pratt Free Library. In the July 25 meeting, Brown contended that her answers to questions regarding the library and her work therein were responsive. ${ }^{102}$ The Mayor asked her about blacklisted famous African American actor and singer Paul Robeson, whose picture hung on one of the library walls. ${ }^{103}$ Brown said she could not place it. ${ }^{104}$ Commissioner Margenau accused her of being a Communist, and Brown replied that she was not. ${ }^{105}$ As the questions shifted from the library and her work to her personal life,

99. Id.

100. Joint Anti-Fascist Refugee Comm. v. McGrath, 341 U.S. 123, 175 n.1 (1951) (Douglas, J., concurring) (describing Ober Law's requirements); Mary Elizabeth Basile, Loyalty Testing for Attorneys: When Is It Necessary and Who Should Decide?, 30 CARDozo L. REV. 1843, 1858 n.73 (2009) ("This statute, The Subversive Activities Act of 1949, Md. Ann. Code art. 85A, § 15, which made the membership in the Communist Party or any organization found to advocate the overthrow of the government a crime, served as a model for other state statutes.").

101. David K. Berninghausen, The Responsibilities of Librarians, 44 ALA Bull., Sept. 1950, at 305, 306 (quoting Council of the ALA through Editor's Note).

102. Censorship in Bartlesville, supra note 54, at 88.

103. Minutes, supra note 92, at 7--2; Paul Robeson was a famous African American actor and singer who was blacklisted in 1950. He was valedictorian at Rutgers, an All-American football player and early NFL star, and a graduate of Columbia Law School. Paul Robeson, WIKIPEDIA, https://en.wikipedia.org/wiki/Paul_Robeson (last visited Oct. 29, 2020) [https://perma.cc/A9FUNTUG].

104. Minutes, supra note 92, at 7--2.

105. Id. 
she stopped answering, stating that she would not answer unless given an option to submit her answers in the form of a written report. ${ }^{106}$ The Mayor did not grant Miss Brown this accommodation. ${ }^{107}$ An hour after the meeting, the city manager fired her. ${ }^{108}$

A group of Bartlesville citizens attended the August Board of Commissioners meeting. ${ }^{109}$ They requested a reason for Brown's termination. ${ }^{110}$ The Mayor said it had nothing to do with any subversive materials subscribed to by the library or Brown's support for African American groups, but rather for her insubordination. ${ }^{111}$ When asked for examples of her insubordination, the Mayor was unable to remember any. ${ }^{112}$

On September 12, 1950, Brown and Darlene Essary, a former member of the Library Board, filed suit in the District Court of Washington County, Oklahoma. ${ }^{113}$ They sought to invalidate Bartlesville Ordinance 1453, which authorized their removal. ${ }^{114}$ The judge in Washington County disqualified himself. ${ }^{115}$ The Oklahoma Supreme Court then assigned the case to another Oklahoma district court. ${ }^{116}$ Brown and Essary lost in District Court, eventually appealing to the Supreme Court of Oklahoma on December 11, $1950 .{ }^{117}$

The American Civil Liberties Union (ACLU), along with the ALA, had offered Brown assistance. ${ }^{118}$ The ACLU even offered legal assistance, but both the ACLU and the ALA stopped short of filing amicus briefs. ${ }^{19}$ The ACLU and the ALA thought the legal argument - that the city commissioners had no legal right to assume control of the library because the State had an overriding interest - was a losing argument. ${ }^{120}$ Both associations thought that arguing the civil liberties issues involved in the case had a more likely chance of success. ${ }^{121}$

106. Id.

107. Id.

108. Id. at 7--3.

109. Letter from M.P. Matuszak to John D. Upham (Sept. 18, 1950), in RUTH W. BrowN PAPERS, 1891-1976 (2018), https://digitalcommons.pittstate.edu/rwb/3/ [https://perma.cc/EL6HB5W8].

110. Id.

111. Id.

112. Censorship in Bartlesville, supra note 54, at 89.

113. Id.; see also Petition in the District Court of Washington County, Oklahoma (Sept. 1950), in RUTH W. BROWN PAPERS, 1891-1976 (2018), https://digitalcommons.pittstate.edu/rwb/64/ [https://perma.cc/R22H-CHLC] (unsigned copy of complaint in Brown v. Dunaway, et al.).

114. Censorship in Bartlesville, supra note 54, at 89.

115. Id.

116. Id.

117. $I d$.

118. Robbins, Racism and Censorship, supra note 56, at 37.

119. Id.

120. Id. at 44 .

121. Id. 
The Oklahoma Supreme Court upheld the lower court, reasoning that the administration of a city library's affairs is a local operation. ${ }^{122}$ "We find no reason to say that such local operation is charged with such a wide public interest as to be a matter of state concern." 123

The ALA complied and helped publicize the incident, but the Intellectual Freedom Committee (IFC), under the leadership of David Berninghausen, fell short. Berninghausen felt constrained by the loyalty-oath controversy and did no more than "suppl[y] the Library Bill of Rights and information about the challenged periodicals . . .." 124 The Library Board used the IFC information in its reports to the City Commission, but the information amounted to only pointless words. ${ }^{125}$

The Ruth Brown incident was the IFC's first on-site investigation of censorship, and despite its less than successful effort, its presence did bring some attention to the Commission. ${ }^{126}$ Ruth Brown called the support offered by the ALA and IFC inadequate in an article she wrote for the Library Journal in 1961. ${ }^{127}$ She stated her disappointment in the ALA and IFC lay with the association's failure to address the racial aspects of the case. ${ }^{128}$

The Ruth Brown incident exposed the weaknesses of the early IFC and the recently revamped 1948 Library Bill of Rights. ${ }^{129}$ Even with the creation of a new Bill of Rights, the IFC did not begin to address African American access to libraries until a decade later. ${ }^{130}$ Librarians reexamined their definition of intellectual freedom to include racial integration after the Ruth Brown case. ${ }^{131}$ Ruth Brown found another job in a public library in Sterling, Colorado. ${ }^{132}$

Loyalty oaths are usually rooted in paranoia. ${ }^{133}$ Adolph Hitler demanded the pledged oath to himself instead of the constitution. ${ }^{134}$ The armed forces, the

122. State ex rel. Brown v. Dunnaway, 248 P.2d 232, 236 (Okla. 1952).

123. Id.

124. Louise S. Robbins, Champions of a Cause: American Librarians and the Library Bill of Rights in the 1950s, 45 LIBR. TRENDS 28 (1996) [hereinafter Robbins, Champions of a Cause].

125. Id.

126. Robbins, Dismissal of Miss Ruth Brown, supra note 26, at 163.

127. Id.

128. Id.

129. Id.

130. Id.

131. Id.

132. Id.

133. Michael S. Rosenwald, From the Civil War to Trump: The Paranoid History of Loyalty Oaths, WASH. Post (June 9, 2017, 12:51 PM), https:/www.washingtonpost.com/news/retropolis/ $\mathrm{wp} / 2017 / 06 / 09 /$ from-lincolns-era-to-trumps-the-paranoid-history-of-loyalty-oaths/ [https://perma.cc/WN5V-G47Y]; see also News Corpse, ASPIRING TYRANT Trump Seeks Loyalty Oaths in Pre-Election Purge, DAILY Kos (July 16, 2020, 6:25 PM), https://www.dailykos. com/stories/2020/7/16/1961328/-ASPIRING-TYRANT-Trump-Seeks-Loyalty-Oaths-in-PreElection-Purge [https://perma.cc/6PS2-GZQ7].

134. Karl Barth, Karl Barth-Rudolf Bultmann Letters, 1922-1966, at 134 (Bernd 
cabinet, the SS, the SA (Nazi paramilitary organization), and the civil service were required to sign the oath. ${ }^{135}$ Like Hitler, President Trump offered himself as the one solution. ${ }^{136}$ His loyalty oath took on an authoritarian flair, not demanding loyalty to the country or the Constitution but instead to himself. ${ }^{137}$

\section{BOSTON PUBLIC LIBRARY}

After the Ruth Brown incident, in reexamining intellectual freedom to include racial integration, the IFC hoped that principle II of the Library Bill of Rights - extolling the virtues of inclusion-would be particularly poignant. Libraries should provide books and other materials "presenting all points of view concerning the problems and issues of our times"; no library materials should be "proscribed or removed from library shelves because of partisan or doctrinal disapproval." "138 Later studies showed that the addition of the Library Bill of Rights to a materials-selection policy could be a factor in the retention of challenged materials. ${ }^{139}$

In September 1952, the Boston Public Library fell under attack by the Boston Post ${ }^{140}$ The Post, a conservative newspaper, attacked the Boston Public Library in a succession of articles for holding Soviet journals and books in their collection. ${ }^{141}$ Pravda, Izvestia, and New World Review ${ }^{142}$ were not out in the library but were available for study and research. ${ }^{143}$ First, the Post recommended removing publications such as the New World Review. ${ }^{144}$ The library director,

Jaspert ed., \& Geoffrey W. Bromiley ed., trans., William B. Eerdmans Publ'g Co. 1981) (1971).

135. Horst von Maltitz, The Evolution of Hitler's Germany: The Ideology, The Personality, The Moment 202 (McGraw-Hill Inc. 1973) (2008).

136. Molly Ball, Donald Trump and the Politics of Fear, AtlantiC (Sept. 2, 2016), https://www.theatlantic.com/politics/archive/2016/09/donald-trump-and-the-politics-offear/498116/ [https://perma.cc/32QY-2RCK].

137. Rosenwald, supra note 133.

138. Am. Library Ass'n, Library Bill of Rights (1948), https://www.loc.gov/item/ rbpe.1000660d/ [https://perma.cc/Z2MR-6VTE].

139. See Dianne McAfee Hopkins, The Library Bill of Rights and School Library Media Programs, 45 LiBR. TRENDS 1 (1996).

140. Stephen Francoeur, McCarthyism and Libraries: Intellectual Freedom Under Fire, 1947-1954, at 26 (2006) (unpublished M.A. thesis, Hunter College, The City University of New York) (on file with the University of Arizona Campus Repository), http://hdl.handle.net/ 10150/133533 [https://perma.cc/VG2S-KLDJ].

141. Boston Board Keeps Red Books in Library, supra note 36.

142. James Rorty, The Attack on Our Libraries: Defending, CommentaRy (June 1955), https:/www.commentarymagazine.com/articles/james-rorty/the-attack-on-our-librariesdefending/ [https://perma.cc/5GMN-PEHJ] (listing titles of Russian publications).

143. Boston Board Keeps Red Books in Library, supra note 36 ("Milton E. Lord, director of the library said that ... Communist material was kept available only for study and research").

144. Francoeur, supra note 140, at 26. 
Milton Lord, made it clear that the library would not be intimidated. ${ }^{145}$ The Post then called for the library to "label the poison." 146

The IFC formally studied the labeling proposed by the Sons of the Revolution (SAR), and nine of the eleven members of the IFC voted against labeling. ${ }^{147}$ Most of the committee members were from large public and institutional libraries. ${ }^{148}$ The concern was that their judgment might not have been representative of the types of libraries that were most likely to be confronted with labeling issues, primarily smaller public libraries. ${ }^{149}$ The IFC identified twenty-four more practicing librarians from smaller libraries located geographically from Minnesota to Texas and from the State of Washington to North Carolina. ${ }^{150}$ Twenty of the twenty-four librarians responded, all opposed to labeling. ${ }^{151}$ The unanimous sample, albeit small, was impressive. ${ }^{152}$

The Boston Post newspaper, termed the "McCarthy Paper," 153 ran a frontpage, eight-column article headlined, "Kremlin Newspapers in Hub Library Reading Room." ${ }^{54}$ The Post article stated that Communist "underlings ... g[o]t the latest dope straight from Moscow at the expense of the Boston taxpayers who are footing the bill for importing Pravda and Izvestia for the Boston Public Library." ${ }^{155}$ Endowment paid for both subscriptions. ${ }^{156}$ The article went on to explain that Communists could translate these Soviet newspapers to our youth. ${ }^{157}$

The article was so suggestive that Boston Library Trustees had the Library staff guard the Reading Room to ensure that Communists were not spreading their doctrine to unsuspecting children. ${ }^{158}$ Two days later, a single-column headline read, "Red Books Bought for Ten Years."159 Following that, the Boston Post ran the headline, "Library Urges Study of Marx."160 It stated, "The Boston Public Library is promoting Communist literature in a large-scale lobby display

145. Id.

146. Id.

147. Labeling - A Report of the ALA Committee on Intellectual Freedom, 45 ALA BuLL., July-Aug. 1951, at 241, 241.

148. Id.

149. Id. at $241-42$.

150. Id. at 242 .

151. Id.

152. Id.

153. Gwirtzman, supra note 6 (also known as "The McCarthy Newspaper" referring to proRed Scare).

154. Kremlin Newspapers, supra note 31.

155. Gwirtzman, supra note 6 (quoting Kremlin Newspapers, supra note 31). Gwirtzman noted that, "[a]ctually, the papers were financed from a private endowment."

156. Id.

157. Id.

158. Id.

159. Arthur Edward Rowse, Slanted News: A Case Study of the Nixon and STEVEnSON Fund Stories 70 (1957).

160. Gwirtzman, supra note 6. 
urging people to read the basic books of Communism."161 It turns out the exhibit was part of a Great Books Foundation display that explored the great works of authors such as Plato, Aquinas, and Thomas Jefferson. ${ }^{162}$

Director Lord admitted to having Communist books in the display and other parts of the library. "It is essential that information on all aspects of political, international, and other questions be available for information purposes in order that citizens of Boston may be informed about the friends and enemies of their country."163 The Post was not swayed: "We believe that pro-Soviet literature should be suppressed in our public libraries. . . . We believe that to permit proCommunists to circulate their poison among our people is sheer stupidity." ${ }^{164}$ The less conservative Boston Herald lectured, "The basic question is whether we still have confidence in the average American's ability to separate bad ideas from good by his own unaided effort. When we lose that confidence, we shall have lost our faith in democracy itself." 165

Library Director Lord initially refused to limit access to any of the so-called subversive material. ${ }^{166}$ However, it was election time, and members of the city council and Mayor John B. Hynes called for restrictions. ${ }^{167}$ The Post sent reporters to the branches of the public library to report on any branches that did not restrict Soviet and pro-Soviet periodicals. ${ }^{168}$

Herbert Philbrick, ${ }^{169}$ an under-cover agent for the FBI and author of I Led 3 Lives: citizen, "Communist," counterspy ${ }^{170}$ (which launched a popular television drama in the 1950s called I Led 3 Lives ${ }^{171}$ ), stated:

Shocked to hear that the Boston Public Library has under consideration the suppression of vital information concerning the methods, nature, and extent of the Soviet conspiracy against the United States. Such suppression would be directly in line with the current policy of the Communist party in the United States to conceal the true aims of the party from all except its trusted members. The Boston Public Library

161. Id.

162. Id.

163. Rorty, supra note 142.

164. Id.

165. Id.

166. Gwirtzman, supra note 6 .

167. Id.

168. Id.

169. Herbert Philbrick was an anticommunist activist and undercover informant for the FBI. Richard Gid Powers, Philbrick, Herbert A., Am. NAT'L Biography (Oct. 2009), http://www. anb.org/articles/15/15-01320.html [https://perma.cc/G8N3-2AP8].

170. Herbert A. Philbrick, I Led 3 Lives: citizen, “Communist,” counterspy (1952).

171. The drama I Led 3 Lives ran 117 episodes from 1953 through 1956. I Led 3 Lives, IMDB, https://www.imdb.com/title/tt0045397/ (last visited Oct. 30, 2020) [https://perma.cc/KBF2-MFC9]. 
should have more, and not less information available to the American people to aid them in their fight against Communism. ${ }^{172}$

“Communist literature that the [Boston Public Library] didn't have, but should have had, in Mr. Philbrick's opinion, included the Daily Worker, the Cominform [Communist Information Bureau] bulletin For a Lasting Peace, for a People's Democracy, and J. Peters' Manual on Party Organization ...."173

The uproar from the Post caused quite a stir, and "[r]epresentatives of local posts of the American Legion and Veterans of Foreign Wars weighed in on the side of the Post." ${ }^{\prime 174}$ The president of the City Council and another councilmember joined the protests against the Public Library. ${ }^{175}$

In the early 1950s, besides the Boston Post, there were other hard-lined antiCommunist newspapers in the United States such as the Denver Post, "the Washington Star, the Pittsburgh Post-Gazette, the Baltimore Sun, the Rochester Democrat and Chronicle, and the Detroit Free Press." 176 These media sources added fuel to the Red Scare fire. Anti-Communist media, however, did not overtake the United States.

Germany was another matter. It was a wealth of free press in the early 1920s. Germany had "seven thousand periodicals serving hundreds of audiences, four thousand daily and weekly newspapers, and a publishing industry that produced thirty thousand books a year." 177 However, gradually due to economic hardship and political unrest, the freedom of the press lost currency. ${ }^{178}$ Hitler was eventually able to gain control of the newspaper publishers' association and place newspapers under Nazi Party control. ${ }^{179}$

Trump would have loved the opportunity to censor any unfavorable press. ${ }^{180}$ A similar contemporary example of a news source espousing the political views of fear and loathing the way the Boston Post did regarding Communists was the Fox News Channel depiction of Muslims and immigrants. ${ }^{181}$ One of Rupert Murdoch's senior executives, Joseph Azam, left his job over Fox News coverage of Muslims, immigrants, and race. ${ }^{182}$ Like the Post's representation of

172. Rorty, supra note 142.

173. Id.

174. Francoeur, supra note 140, at 27.

175. Rorty, supra note 142.

176. Masuda Hajimu, Cold War Crucible: The Korean Conflict and the Postwar WORLD 104-05 (2015).

177. Gary S. Messinger, The Battle for the Mind: War and Peace in the Era of Mass COMMUNICATION 72 (2011).

178. Id.

179. Id.

180. Graham, supra note 46.

181. David Folkenflik, Former Murdoch Executive Says He Quit Over Fox's Anti-Muslim Rhetoric, NPR (Mar. 21, 2019, 4:15 PM), https://www.npr.org/2019/03/21/705441083/formermurdoch-executive-says-he-quit-over-foxs-anti-muslim-rhetoric [https://perma.cc/R7UU-7QJ9].

182. Id. 
Communists, Azam stated that Fox News Channel was "[s]caring people. Demonizing immigrants. Creating, like, a fervor - or an anxiety about what was happening in our country." 183

In addition to Herbert Philbrick and the Boston Herald, others supported the Boston Public Library's defense of the principle of free inquiry, including the Christian Science Monitor, the Pilot (a Catholic diocesan paper), and two-thirds of the Boston Public Library staff (who signed a petition asking the five trustees to support the Library). ${ }^{184}$

Before the Board of Trustees of the Library was to vote on the censors, four councilmembers attended an open meeting. ${ }^{185}$ Attendees expressed opposition to the Boston Public Library's open policy. ${ }^{186}$ But the very next day, the Trustees voted three to two to pass a resolution supporting the Library in collecting materials that represented all points of view and making them openly available to the public. ${ }^{187}$ The vote stated that there should be no restrictions placed on what the public can and cannot read. ${ }^{188}$

The two trustees who voted against the Director's position of free inquiry were Frank J. Donahue, an Associate Judge of the Massachusetts Superior Court ${ }^{189}$ who also served as the Massachusetts Secretary of the Commonwealth, ${ }^{190}$ and Patrick F. MacDonald, ${ }^{191}$ a steel merchant.

The three votes in support of the Library were Frank W. Buxton, a retired newspaper editor ${ }^{192}$ awarded the Pulitzer Prize for a political editorial in 1924 while working at the Boston Herald ${ }^{193}$; Lee M. Friedman, noted book collector and lawyer ${ }^{194}$; and the Right Reverend Robert H. Lord (no relation to Milton Lord), Harvard Professor and Catholic priest. ${ }^{195}$ The crucial support of the Catholic Church in Boston emerged. "Director Milton Lord had helped in the [classification and] cataloguing of the Vatican Library in Rome" in the 1920s, and "the Catholic archbishop of the [Boston] diocese [later] became a member of

183. Id.

184. Rorty, supra note 142.

185. Id.

186. Id.

187. Id.

188. Id.

189. Michael E. Hennessy, Four Decades of Massachusetts Politics, 1890-1935, at 153 (1935).

190. Id. at 544.

191. Rorty, supra note 142.

192. Id.

193. Frank W. Buxton, Who Made Coolidge?, in 4 The Pulitzer Prize Archive: Political EDitorial 1916-1988, at 31, 31 (Heinz-Dietrich Fischer \& Erika J. Fischer eds., 1990) (1923).

194. Rorty, supra note 142.

195. Id. 
the five-man library board." ${ }^{\prime 196}$ The Church had maintained a presence since that time. ${ }^{197}$

\section{SAN ANTONIO MINUTE WOMEN}

In November of 1952, a housewife, Myrtle G. Hance — organizer of the San Antonio chapter of Minute Women of the U.S.A., an ultra-patriotic conservative organization $^{198}$ - took it upon herself to go through the library catalog to identify over 574 Communist books. ${ }^{199}$ Of the 118 authors associated with these books, nine were "admitted" Communists, and the others were associated with Communist-front affiliations. ${ }^{200}$

The Minute Women of the U.S.A. attracted middle-class homemakers and mothers. ${ }^{201}$ The national organization claimed in 1952 to have 500,000 members, but later sources stated there were around $50,000 .{ }^{202}$ The group was particularly strong in Connecticut, California, Maryland, Texas, and West Virginia. ${ }^{203}$ The political action group dedicated themselves to fighting communism and removing its supporters and sympathizers from state and federal government and schools. ${ }^{204}$ The Minute Women of the U.S.A., focusing on their patriotic role of homemakers, editorialized that, "of course, they [communists and fellow travelers] want us [women] to go to work so they can take over the indoctrination of our children - making them into one-worlders and zombies."205

Myrtle G. Hance's list included books addressing physics, sculpture, childcare, alcoholism, mental illness, architecture, as well as mystery fiction and

196. Id.; see Donald G. Davis, Jr., Milton Edward Lord (1898-1985), in Supplement to the Dictionary OF AMERICAN LibraRy BIOGRAPHy 52 (Wayne A. Wiegand ed., 1990).

197. Rorty, supra note 142.

198. Francoeur, supra note 140, at 56.

199. The number varies by source. See e.g., San Antonio Public Library: Censorship Divides the Community, SAN ANTONiO Remembers (Mar. 22, 2009), http://sanantonioremembers. blogspot.com/2009/03/san-antonio-public-library-censorship.html [https://perma.cc/QL6Y-P28H] (lists 574 Communist books by 118 authors, nine of which were "admitted" Communists and the others had Communist-front affiliations); Rorty, supra note 142 (lists the number of books to be six hundred); It Didn't Happen Here, TIME, Jan. 18, 1954, at 98 (lists the number of books to be six hundred); Branding of Books Stirs Texas Battle, N.Y. Times, June 7, 1953, at 61 (listed the number at "about 600").

200. San Antonio Public Library: Censorship Divides the Community, supra note 199; Francoeur, supra note 140, at 56.

201. Patricia Carol Walls, Defending Their Liberties: Women's Organizations During the McCarthy Era 176 (1994) (unpublished Ph.D. dissertation, University of Maryland).

202. Id.

203. Id. at 177.

204. Id.

205. Mary C. Brennan, Wives, Mothers, and the Red Menace: Conservative Women and the Crusade Against Communism 94-95 (2008). 
romantic poetry. ${ }^{206}$ The list included Thomas Mann's Joseph in Egypt, Essays of Three Decades, and The Magic Mountain; Louis Untermeyer's Treasury of American and British Poetry; Dorothy Canfield Fisher's Fables for Parents and Understood Betsy; Allan Lomax's collection of American folksongs; and Norbert Wiener's Cybernetics. ${ }^{207}$

The Canterbury Tales and Moby Dick were on the list because of illustrations done by a suspected Communist, Rockwell Kent. ${ }^{208}$ American poet, short-story writer, and screenwriter Dorothy Parker had items on the list. ${ }^{209}$ Louis Adamic, an American novelist and journalist, wrote about the oppressive conditions of American minorities, especially immigrants. ${ }^{210}$ Harlow Shapley, who deduced that the sun lies near the galaxy's central plane, ${ }^{211}$ had his work on the list, as did Norman Corwin, American radio writer, producer, and director, dubbed the poet laureate of radio. ${ }^{212}$

Karen White, the Mayor's wife, another like-minded Minute Woman, was friends with Hance. ${ }^{213}$ Mayor White supported his wife. On May 14, 1953, the San Antonio City Council discussed the Communist books at the Public Library. ${ }^{214}$ Mayor White stated, "I would like to put a thought to the council that they should be looking into the matter of stamping books in the public library by known Communists." 215

Acting City Manager Wylie Johnson stated in reply, "I think they should be burned instead of stamped." ${ }^{216}$ City Librarian Julia Grothaus clarified the Public Library's position:

Of course the library has always had books on controversial subjects. ...

The library has never dictated to the people what they should have and

206. Branding of Books Stirs Texas Battle, supra note 199.

207. Id.

208. Id.

209. Id.; Dorothy Parker, Goodreads, https://www.goodreads.com/author/show/24956. Dorothy_Parker (last visited Oct. 30, 2020) [https://perma.cc/BD3E-QSXG]; Dorothy Parker, ENCYCLOPAEDIA BRITANNICA (Aug. 18, 2020), https://www.britannica.com/biography/DorothyParker [https://perma.cc/KH5G-22UN].

210. Branding of Books Stirs Texas Battle, supra note 199; Louis Adamic, ENCYClOPAEDIA BRITANNICA (Mar. 19, 2020), https://www.britannica.com/biography/Louis-Adamic [https://perma. cc/Q2WU-3HEL].

211. Branding of Books Stirs Texas Battle, supra note 199; Harlow Shapley, ENCYCLOPAEDIA BRITANNICA (Oct. 29, 2019), https://www.britannica.com/biography/Harlow-Shapley [https:// perma.cc/K24B-RYQN].

212. Branding of Books Stirs Texas Battle, supra note 199; Norman Lewis Corwin, EnCYClOPAEDIA BRITANNICA (Apr. 29, 2020), https:/www.britannica.com/biography/NormanCorwin [https://perma.cc/X2DD-NYMY].

213. See Rorty, supra note 142.

214. San Antonio Public Library Book Censorship, supra note 39.

215. Id.

216. Id. 
what they should think. We do have material that will give people the information on both sides of the question. That's the policy of my library serving the people. ${ }^{217}$

The San Antonio Public Library Board of Trustees met later that same day and resolved that the Library would not censor books. The board president, a thirty-three-year member, announced the unanimous decision: "These are the very tactics which the Russians are using to fight us. . . . It is ironic that here in San Antonio, which prides itself on its freedom to think and act, that we shall run up against a sample of Communistic tactics." 18

Following this announcement, Johnson "immediately called for the removal of all fifteen board members." ${ }^{219}$ The City Council held a closed meeting on Friday, May 15th, the next day. ${ }^{220}$ The torn council was considering whether to stamp the so-called Communist books or to burn them. ${ }^{21}$ "Council[member] Henry B. Gonzalez ${ }^{222}$ called the burning of books 'Hitler tactics." "'223 In the June 5, 1953, closed meeting, the San Antonio City Council "replaced all but two of the fifteen members of the library board." 224

On June 14, 1953, the Washington Post published an editorial condemning "some Americans" in San Antonio who "have departed from the fundamental beliefs on which this country grew and prospered ...."225 The new Library Board of Trustees tried to put the controversy behind them on February 11, 1954, by "adopting the American Library Association's 'Bill of Rights for Public Libraries.' The vote was six to five."226

It is no surprise that Nazi Germany had a heavy hand in public library collection development. Between 1934 and 1938, for instance, in Essen, Germany, a purge of $69 \%$ of the public libraries' collections were replaced with

217. Id

218. Id.

219. Id.

220. Id.

221. Id.

222. González left the city council in 1956 to become a member of the Texas State Senate until 1961, when he was elected by special election to fill the vacancy following the resignation of United States Representative Paul J. Kilday. González was reelected to eighteen succeeding Congresses (November 4, 1961-January 3, 1999). González, Henry B. (1916-2000), BiOGRAPHICAL DiRECTORY OF U.S. CONG., https://bioguideretro.congress.gov/Home/MemberDetails?memIndex= G000272 (last visited Oct. 30, 2020) [https://perma.cc/5R27-4KYC].

223. San Antonio Public Library Book Censorship, supra note 39.

224. San Antonio Public Library: City Council vs. Library Board, SAN ANTONio Remembers (Mar. 22, 2009), http://sanantonioremembers.blogspot.com/2009/03/san-antonio-public-librarycity-council.html [https://perma.cc/867Y-3A7G] [hereinafter City Council vs. Library Board].

225. These Books Weren't Burned, WASH. Post, June 14, 1953, at B4.

226. City Council vs. Library Board, supra note 224. 
collections conforming to Nazi ideological principles. ${ }^{227}$ Librarians followed an official Nazi library blacklist in earnest. ${ }^{228}$

In President Trump's second year in office, he had his attorney write a ceaseand-desist letter to author Michael Wolff and his publisher to suppress the release of Wolff's book, Fire and Fury: Inside the Trump White House ${ }^{229}$ Prior restraint of constitutionally protected speech, such as what happened with the Pentagon Papers, is unconstitutional and almost unheard of in democratic societies. ${ }^{230}$ As Ed Kilgore states, "Banning books and burning books are essentially the same thing." 231

\section{MCCARTHY, OVERSEAS LIBRARIES, IKE, AND THE FREEDOM TO READ}

President Eisenhower formed the United States Information Agency (USIA) in $1953 .^{232}$ The agency supports American foreign policy and interests through various international programs. ${ }^{233}$ One of the programs created overseas libraries through the United States Information Service (USIS); most of the libraries had been created during World War II and were run during the war by the Office of War Information, and later by the Department of State..$^{234}$

Senator McCarthy turned his attention in March of 1953 to supposed Communist authors whose books were on the shelves in the overseas libraries. During the Voice of America (VOA) hearings ${ }^{235}$ McCarthy delivered an early warning to the overseas libraries. ${ }^{236}$ He subpoenaed and questioned Howard Fast,

227. Alan E. Steinweis, Public Libraries in Nazi Germany, by Margaret F. Stieg, 25 CENT. EUR. Hist. 117, 118 (1992) (book review).

228. Id.

229. Ed Kilgore, Trump's Scary Lurch into Book-Banning, N.Y. InTELLIGENCER (Jan. 4, 2018), https://nymag.com/intelligencer/2018/01/trumps-scary-lurch-into-book-banning.html [https://perma.cc/W3DC-DUE9] (The article showed a picture of Hitler youth burning piles of books).

230. Id.

231. Id.

232. Paul P. Kennedy, Eisenhower Gives Information Plan to Reassure World on U.S. Aims, N.Y. TIMES, Oct. 29, 1953, at 1.

233. Ruby LeGault, USIS Libraries, LIBR. HIST. TIMELINE, http://libraryhistory.pbworks.com/ w/page/16964742/USIS\%20Libraries (last visited Oct. 30, 2020) [https://perma.cc/QT4J-ENRF].

234. $I d$.

235. Records of McCarthy Anti-Communism Hearings Released - 2003-05-05, VoICE OF AM. (Oct. 30, 2009, 2:12 PM), https://www.voanews.com/archive/records-mccarthy-anti-communismhearings-released-2003-05-05 [https://perma.cc/SUU7-AA5N] (There were eleven VOA hearings).

236. The VOA is an airwaves agency, and the United States' first parlay into international airwaves. The VOA hit the international airwaves on February 1, 1942, fifty-six days after the attack on Pearl Harbor. Chris Kern, A Belated Correction: The Real First Broadcast of the Voice of America, Chris Kern: Essays \& PHOTOGRAPHS (Sept. 2010), http://www.chriskern.net/essay/ voaFirstBroadcast.html [https://perma.cc/TV3T-RS7J]. When the subcommittee hearings on the VOA took place, starting in February 1953 and ending in April of that same year, the VOA took 
probably most famous for his novels Spartacus and Citizen Tom Paine. ${ }^{237}$ Fast had never worked for the VOA and had no previous connection to the agency. ${ }^{238}$ But a mention of his name appeared in a February 1953 State Department memorandum to the VOA and the State Department's International Information Administration (IIA) ${ }^{239}$ On the State Department's list were nine of Howard Fast's novels. ${ }^{240}$

McCarthy ranted against the State Department, demanding, and then receiving the "prompt removal" of Howard Fast books from VOA libraries "everywhere in the world." ${ }^{241}$ Also, McCarthy took this opportunity to blast the overseas libraries' collection-development plan, stating that it was an "automatic capitulation to the Communists." ${ }^{242}$

On February 18, 1953, during McCarthy's inquiry into the VOA, Howard Fast was called to testify. ${ }^{243}$ Roy Cohn, ${ }^{244}$ a young lawyer and investigator working for McCarthy, asked Howard Fast four times if he was a Communist. ${ }^{245}$ Fast invoked the Fifth Amendment each time. ${ }^{246}$ Chairman McCarthy got Howard Fast to invoke the Fifth Amendment six different times that day. ${ }^{247}$ Senator McCarthy asked Mr. Fast if he knew "any other members of the Communist Party working in OWI [Office of War Information] at the time" he was working in

a beating. The McCarthy hearings represented the low point for the VOA. The VOA barely survived the onslaught, and it took years for the agency to recover. The VOA hearings were a precursor to the overseas libraries hearings that would follow in the spring and summer of 1953 . State Department Information Program -- Voice of America: Hearing on S.R. 40 Before the Permanent Subcomm. on Investigations of the Comm. on Gov't Operation, 83d Cong. (1953) (generally).

237. Gerald Sorin, Howard Fast:Life and Literature in the Left Lane 229-33, 267-68 (2012).

238. Robert Justin Goldstein, Political Repression in Modern America from 1870 TO 1976, at 336 (Rev. ed. 2001).

239. Id.

240. SORIN, supra note 237.

241. Id.

242. Id.

243. State Department Information Program -- Voice of America: Hearing on S.R. 40 Before the Permanent Subcomm. on Investigations of the S. Comm. on Gov't Operation, 83d Cong. 98 (1953) (testimony of Howard Fast, author) [hereinafter Howard Fast Testimony]; LAURA A. Belmonte, Selling the American Way: U.S. Propaganda and the Cold War 52 (2008).

244. Cohn is primarily known for three things: He played a prominent role in the 1951 espionage trial of the Rosenbergs, he was the chief counsel for Senator Joseph McCarthy during 1953 and 1954, and he was Donald Trump's attorney and mentor from 1973 to 1985. Roy Cohn, WIKIPEDIA, https://en.wikipedia.org/wiki/Roy_Cohn (last visited Oct. 14, 2020) [https://perma. $\mathrm{cc} /$ Y85T-56X4].

245. Howard Fast Testimony, supra note 243, at 98.

246. Id.

247. Id. at 99-100. 
OWI. ${ }^{248}$ McCarthy then asked Fast if he knew "anyone in the Voice of America as of today who is a member of the Communist Party?"249

As with McCarthy, Trump attacked the "Voice of America"-once again without proof. ${ }^{250}$ The White House accused the VOA of promoting foreign propaganda when the VOA stated that China's Wuhan lockdown in response to COVID-19 was a successful model and copied around the world. ${ }^{251}$ The VOA followed with a tweet showing a video of the Communist government displaying a celebratory light show. ${ }^{252}$

The White House suggested that the VOA was un-American. "VOA too often speaks for America's adversaries - not its citizens." ${ }^{253}$ Trump's anger was exacerbated by the fact that his nominee to run the Agency for Global Media, which oversees the VOA, had been sitting in committee. ${ }^{254}$ Trump personally intervened and got Michael Pack, a conservative filmmaker and ally of Stephen Bannon, ${ }^{255}$ successfully confirmed by the U.S. Senate on June 4, $2020 .{ }^{256}$

Like McCarthy, Trump defamed leadership with unsubstantiated charges. ${ }^{257}$ Without mentioning her by name, Trump attacked VOA director Amanda Bennett: "'Look at what they're doing and what they're saying about our country,' he said. 'It's a disgrace - the people that [sic] are running that." ${ }^{258} \mathrm{In}$ the same breath, Trump praised his nominee, Michael Pack, and insinuated the current VOA leadership as unpatriotic. ${ }^{259}$ Pack is "somebody that's really good, really talented, and that loves our country." 260

248. Id. at 99.

249. Id. at 100 .

250. Colbert I. King, Trump's Attack on the VOA Reeks of McCarthyism, WASH. Post (Apr. 18, 2020, 8:00 AM), https:/www.washingtonpost.com/opinions/2020/04/18/trumps-attack-voareeks-mccarthyism/ [https://perma.cc/NMX5-KWPQ].

251. Id.

252. Paul Farhi, White House Attacks Voice of America, Claiming It Promoted Chinese Propaganda, WASH. Post (Apr. 10, 2020, 7:33 PM), https:/www.washingtonpost.com/lifestyle/ media/white-house-attacks-voice-of-america-claiming-it-is-promoting-chinesepropaganda/2020/04/10/b59bddea-7b6f-11ea-9bee-c5bf9d2e3288_story.html [https://perma.cc/BMU9-A6VX].

253. King, supra note 250 .

254. Id.

255. "[Bannon] served as the White House Chief Strategist in the administration of U.S. President Donald Trump during the first seven months of Trump's term." Steve Bannon, WIKIPEDIA, https://en.wikipedia.org/wiki/Steve_Bannon (last modified July 12, 2020) [https:// perma.cc/CA7Y-H5TJ].

256. Catie Edmondson, Senate Confirms Conservative Filmmaker to Lead U.S. Media Agency, N.Y. Times (June 4, 2020), https://www.nytimes.com/2020/06/04/us/politics/senate-confirmsmichael-pack-voa.html [https://perma.cc/T62M-DW7S].

257. King, supra note 250.

258. Id.

259. Id.

260. Id. 
Next, McCarthy asked Fast whether he had "any friends in the State Department as of today who are members of the Communist Party?"261 Following that, McCarthy asked Fast whether he was "a member of the Communist Party at the time (he) wrote those books which the Army reprinted?"262 Finally, McCarthy asked Fast whether he was a "member of the Communist Party at the time [he] wrote the books the State Department finally translated and distributed." $" 263$

McCarthy's main objective was to attack a directive written on February 3, 1953, by Harvard Libraries Director Keyes Metcalf; Director of the Library and Library School at the University of Illinois and ALA President Robert B. Downs; Cass Canfield of Harper and Brothers Publishers; and George Brett of Macmillan Publishers. ${ }^{264}$ The directive stated that librarians are to judge materials primarily by their content. ${ }^{265}$

Secretary of State John Foster Dulles and W. Bradley Connors, Assistant Administrator for Policy and Plans for the IIA, attempted to appease McCarthy the next day by replacing the earlier directive with a new directive issued on February 19, 1953, ${ }^{266}$ called the "Information Guide 272." ${ }^{267}$ The new directive placed a moratorium on the use of any "books, music and paintings [by] 'any communists, fellow travelers, etc." "268 The new directive created a "Pandora's box of confusion" for the 196 overseas libraries in sixty-four different countries. ${ }^{269}$ At the February 19 hearing, the new directive came to light during McCarthy's questioning of Connors:

The ChaIRMan. Mr. Connors, let me ask you this: Have you changed your mind? Do you think now that we should not distribute the works of known Communist authors through the information program, or do you still think that some of their books should be used?

Mr. ConNors. I think that you have a use for some of them in trying to convince leftwingers and fellow travelers if you have something that has material that is favorable to the United States, is not opposed to any of our policies or principles. You might be able to use it to influence a leftwinger, a fellow traveler, and as a result of an effort in that way, then give him some other materials which would be 100 percent American.

The ChaIRMAN. In other words, give him some Communist materialMr. ConNORS. That is a little bait.

261. Howard Fast Testimony, supra note 243, at 100.

262. Id.

263. Id.

264. Robbins, Overseas Libraries Controversy, supra note 42, at 29.

265. Id.

266. GoldSTEIN, supra note 238, at 335-36.

267. SORIN, supra note 237, at 270.

268. GoldSTEIN, supra note 238 , at 336.

269. Robbins, Overseas Libraries Controversy, supra note 42, at 29. 
The ChaIRMan. And some American material. Yesterday I understand you told the staff that you could not define the theory of communism, that you could not describe the practices of the Communist Party; is that correct?

Mr. ConNORS. Well, I think-

The ChaIRMAN. Is that essentially correct?

Mr. CONNORS. That is what happened yesterday.

The ChaIRMAN. If that is true, then how can you take a book written by a very clever Communist author, and determine whether it should be used or not, if you say you cannot define communism in theory or in practice?

Mr. CONNORS. The determination of the books is not my responsibility. The ChaIRMAN. Do you not make the final decision?

Mr. CONNORS. No.

The Chairman. Who makes the final decision on the question of books?

Mr. CONNORS. The final decision on the question of books is made by the Assistant Administrator for the International Information Center Service.

The ChaIRMan. So your thought as of today is that as Director of Policy for the information program you should allow the use of Communist books and leave it up to someone else of discretion as to which Communist books should be used.

Mr. CONNORS. No sir, I do not agree to that.

The ChaIRMan. All right. As of today do you think you should issue an order saying no Communist books should be used?

Mr. CONNORS. There is such an order. ${ }^{270}$

The lack of specificity in the new overseas libraries directive led to much confusion among the administrators of the overseas libraries. ${ }^{271}$ Soon, more written separate directives established what the overseas libraries could collect. ${ }^{272}$ Most of the libraries started to remove books, placing them in storage, including works of noted authors-Bert Andrews, Washington Bureau Chief of the New York Herald Tribune; Joseph Davies, former Moscow Ambassador; Vera Micheles, Dean of the Foreign Policy Association; Walter White, head of the NAACP; and Foster Rhea Dulles, cousin of the Secretary of State. ${ }^{273}$ With storage underway, the overseas library in Tokyo, Japan, decided to burn books. ${ }^{274}$

270. State Department Information Program -- Voice of America: Hearing on S.R. 40 Before the Permanent Subcomm. on Investigations of the S. Comm. on Gov't Operation, 83d Cong. 134 (1953) (testimony of Bradley W. Connors, Assistant Administrator for Policy \& Plans, U.S. International Information Administration).

271. SoRIN, supra note 237, at 270.

272. Robbins, Overseas Libraries Controversy, supra note 42, at 29.

273. GOLDSTEIN, supra note 238, at 336.

274. SORIN, supra note 237, at 270. 
On March 24, 1953, the State Department Information Program session on the Information Centers started. ${ }^{275}$ The Chair of these proceedings, McCarthy, took this opportunity to explain his patriotic vision. McCarthy was obsessed with purging the overseas libraries of books authored by Communists. "Most of the[] books [were] inherited from army overstock, purchased during the honeymoon of the wartime Grand Alliance." 276 McCarthy started the proceedings by addressing Counsel Cohn:

The ChaIRMan. The hearing will come to order.

Mr. Cohn, did you have something you wanted to put in the record before we start?

Mr. CoHN. I did, Mr. Chairman.

At your request, we contacted the Department of State in connection with our investigation of the information centers, a part of the information program of the Department of State, and asked them what their objective was in establishing these some 150 information centers throughout the world. They sent us a very brief letter defining that objective. I would like to read that for the record, if I may:

\section{DEPARTMENT OF STATE.}

MY DEAR SENATOR MCCARTHY: In response to Mr. Schine's request of today to state in a simple sentence the purpose of the overseas library program, perhaps the following will suit the committee's needs:

The overseas library program exists to reflect American objectives, values, the nature of American institutions and life, and to utilize the book and related materials to advance the ideas of America in the struggles against communism.

Sincerely yours,

RICHARD HUMPHREY, Acting Director, Information Center Service, Department of State.

The ChaIRMAN. Mr. Cohn, have you determined how many libraries we have throughout the world?

Mr. COHN. I think there are approximately 150, slightly more than that, Mr. Chairman, under the sponsorship of the State Department, in every continent in the world.

275. State Department Information Program - Information Centers: Hearing on S.R. 40 Before the Permanent Subcomm. on Investigation of the S. Comm. on Gov't Operations, 83d Cong. (1953) [hereinafter Overseas Libraries Hearing].

276. Rorty, supra note 142. 
The ChaIRMAn. Just for the sake of the world, will you give us a quick rundown of how you got the names of all the authors and the verification of them?

Mr. CoHN. Yes. At the Library of Congress there is maintained what is known as a master file, and that master file indicates the location in these 150 State Department information centers of books, by titles and by author. So if we want to see where books by a certain author are located anywhere throughout the world in the State Department information centers, we merely check with those master files under the name of the book and under the name of the author, and we will get the information. That has been done by the Library of Congress at our request. There is merely a mechanical function in keeping these cards, but they have supplied us with the information.

At your request, Mr. Chairman, we sought to determine whether or not any books by Communist Party members or known Communists were being used in the State Department information centers. We have been told by the State Department, of course, that they don't think any of these books can be used or should be used.

The CHAIRMAN. May I say that my check indicates that as far as we can determine, no books by Communist authors have been purchased since the new administration has taken over.

Mr. COHN. We have that assurance in writing, Mr. Chairman. ${ }^{277}$

The first witness that day was James S. Allen, an organizer, Marxist scholar, writer, and editor for the Southern Worker, a regional newspaper of the American Communist Party. ${ }^{278}$ Three of Allen's books, The Negro Question in the United States (1936), Reconstruction: The Battle for Democracy (1937), and American Communism and Black Americans (with Philip Foner, 1987), reflected Allen's American experiences in the South and his primary focus on abused African Americans in the South. ${ }^{279}$ McCarthy's questioning of Allen was indicative of the curt and uncivil manner he approached most witnesses:

The ChaIRMan. Were you the foreign editor of the Communist Daily Worker?

Mr. ALLEN. I refuse to answer that question on the basis of my privilege under the fifth amendment, since it might tend to incriminate me.

The CHAIRMan. Senator Dirksen has pointed out that that involved a statement of fact. I doubt very much that you have the privilege to refuse to answer that question. However, the privilege always has been interpreted very broadly by the courts. It is common knowledge that this

277. Overseas Libraries Hearing, supra note 275, at Part 1, 1-2. (statement by Roy Cohn).

278. Guide to the James S. Allen Papers TAM.142, TAmiment Libr. \& RoBert F. Wagner LAB. ARCHIVE, http://dlib.nyu.edu/findingaids/html/tamwag/tam_142/bioghist.html (last visited Oct. 9, 2020) [https://perma.cc/G53R-4LD5].

279. Id. 
man was foreign editor of the Daily Worker, so I assume it is not too important whether he answers it or not.

Mr. Allen, do you know a single member of the staff of the Daily Worker who is not a member of the Communist Party?

Mr. ALLEN. I refuse to answer that question, on the grounds previously stated.

The Chairman. On the grounds that your answer might incriminate you?

Mr. ALLEN. Yes, sir.

The ChaIRMAN. While you were foreign editor of the Daily Worker, did you get instructions from Moscow as to what the party line should be?

Mr. AlLEN. I refuse to answer that question, on the grounds of possible self-incrimination, that it might tend to incriminate me. I also would like to point out that I have previously refused to answer the question as to whether I was foreign editor of the Daily Worker, and that was implied in your question. ${ }^{280}$

Not all of the people asked to testify were antagonistic to McCarthy's witchhunt. Fordham Professor Louis Francis Budenz, a former managing editor for the Daily Worker and President of the Freedom of the Press Company, managed the Daily Worker. ${ }^{281}$ Budenz turned out to be a prominent McCarthy rainmaker. Budenz had been a high-level member of the American Communist Party until 1945 when he joined the Roman Catholic Church and renounced Communism. ${ }^{282}$ The following testimony depicts just how helpful Budenz was to McCarthy's cause:

The Chairman. May I interrupt, Mr. Cohn?

I think we should have the record very clear that Mr. Budenz has been of almost untold value to the FBI and to the Government since he has broken with the Communist Party. If it had not been for Mr. Budenz' testimony, a sizable number of Communists who have either been deported or sent to jail would still be free.

I think it is a great service you have rendered to this country, Mr. Budenz, since you broke with the party.

Mr. BUDENZ. Thank you, Senator.

Mr. CoHN. As a matter of fact, Mr. Budenz, you were the first and the principal witness for the United States Government at the trial of the 12 top Communist leaders in New York a few years ago, and once again you were the first and principal witness at the trial of the 13 second-string

280. Overseas Libraries Hearing, supra note 275, at Part 1, 4.

281. Tax-Exempt Foundations: Hearings on H.R. 561 Before the H. Select Comm. to Investigate Tax-Exempt Found. \& Comparable Orgs., 82d Cong. 716 (1953) (testimony of Louis Francis Budenz, Member of the Faculty of Fordham University and Seton Hall University).

282. John Simkin, Louis Budenz, Spartacus EDUC., https://spartacus-educational.com/ USAbudenz.htm (last updated Jan. 2020) [https://perma.cc/J7YJ-WLMQ]. 
Communist leaders who were just convicted by a jury in New York a few weeks ago. Is that correct?

Mr. BuDENZ. Yes, sir. And, as a matter of fact, the indictment was passed upon my analysis of the constitution of the Communist Party, made for the Federal Bureau of Investigation, though I did not know it was to be used for that purpose at that time.

Mr. COHN. And you have given, with no compensation, thousands of hours of your time to the Federal Bureau of Investigation. Is that right? Mr. BUDENZ. Yes, sir; very gladly. I consider it the soundest agency of the Government. ${ }^{283}$

A little later in his testimony, Budenz pointed out how many authors represented on the shelves of the overseas libraries were known Communists:

Mr. CoHN. Now, Professor Budenz, we asked you to come down here today because the committee is now investigating the information program of the United States State Department, and part of that information program included some over 150 information centers throughout the world which contain libraries, which libraries contain a selection of books, the purpose of which is to give people throughout the world a true picture of the American way of life, and "to advance," quoting from the official statement of the head operating agency of the State Department, "the ideas of America in the struggles against communism."

I will ask you this question, Professor Budenz: Have you, at the request of the committee, examined a partial list of some authors whose books we have been advised by the Library of Congress are currently being used by the State Department in its information program?

Mr. BUDENZ. Yes, sir, I have gone over that list.

Mr. CoHN. On that list, did you find any authors who were known to you as Communists?

Mr. BUDENZ. Yes, sir, I did.

Mr. COHN. Approximately how many?

Mr. BUDENZ. At least 75; and 4 that had very close connections with the Communist Party. ${ }^{284}$

Part I of the IIA's information center hearings finished after three days on March 26, 1953; Part II of the proceedings occurred on March 27, April 1, and April 2, and examined authors Grace Lumpkin, Morris Schappes, Bernard Stern, and Gene Weltfish. ${ }^{285}$ Cohn and Schine then undertook a whirlwind tour of overseas libraries in Europe. ${ }^{286}$ On April 4, 1953, the journey started in Paris and

283. Overseas Libraries Hearing, supra note 275 , at Part 1, 42-43.

284. Id. at Part 1, 43-44.

285. Id. at Part 1, I; Id. at Part 2, I.

286. David M. Oshinsky, ACONSPIRACy So ImMense: The World of Joe MCCARThy 279 (1983) 
ended in London on April 21 with stops in between at Berlin, Frankfurt, Munich, Bonn, Vienna, Belgrade, Athens, and Rome. ${ }^{287}$

Cohn and Schine's work led to the removal of at least twenty-five additional authors from the overseas libraries' shelves. ${ }^{288}$ According to one account, the accuracy of the information that Cohn and Schine supplied to McCarthy was suspect; Freda Utley, author, lecturer, and newspaper correspondent, stated that she met Cohn and Schine during their Communist book investigation, and "they managed to mix up the lists I had given them of books in the Amerika Haus libraries in Germany, presenting my compilation of anti-Communist books . . . as pro-Communist books!"289

Utley went on to describe Cohn and Schine as two ignorant, "unscrupulous careerists. ${ }^{" 290}$ Christian Science Monitor foreign correspondent Edmund Stevens wrote that Cohn and Schine aided the Italian Communists by placing in storage some of the "most effective anti-Communist propaganda ever to appear in Italy. ${ }^{291}$ Despite their methods, Cohn and Schine's work, as stated above, ${ }^{292}$ sufficiently spooked the Department of State into storing additional books from the overseas library shelves and adding to the list of suspected authors. ${ }^{293}$ The burning of books took place during this period. ${ }^{294}$

After Cohn and Schine finished the tour through the overseas libraries, the Deputy Director of the Office of Public Affairs for the High Commissioner, Theodore Kaghan, ${ }^{295}$ called the traveling duo the "junketeering gumshoes." 296 During the continuing hearings on April 29, 1953, McCarthy called upon Kaghan to testify in his efforts to "get" Kaghan. ${ }^{297}$ The State Department would later fire Kaghan. ${ }^{298}$ McCarthy's questioning of Kaghan was aimed at defining him as a Communist:

287. Id.

288. Verboten Volumes, TIME, June 22, 1953, at 34-36.

289. Freda Utley, Odyssey of a Liberal, Memoirs 279 (1970).

290. Id.

291. Lawrence N. Strout, Covering McCarthyism: How the Christian Science Monitor Handled Joseph R. MCCARThy, 1950-1954, at 99 (1999); Sowing Seeds of Disunity, Progressive, Apr. 1954, at 86, http://galenfrysinger.com/seeds_of_disunity.htm [https://perma. cc/4KSL-SA2Q].

292. See Verboten Volumes, supra note 288 and accompanying text.

293. Wilson P. Dizard JR., Inventing Public Diplomacy: The Story of the U.S. INFORMATION AGENCY 57 (2004).

294. Strout, supra note 291 , at 99.

295. Albert Fried, McCarthyism: The Great American Red Scare: A Documentary HISTORY 93 (1997).

296. Ted Morgan, Reds: McCarthyism in Twentieth-Century America 444 (2004).

297. Id.

298. Id. 
The Chairman. Have you made any attempt to get the names of the individuals who were responsible for putting the Communist works on your shelves?

Mr. KAGHAN. I personally have not; no, sir.

The CHAIRMAN. If you would get his name, and if you had the power to fire him, would you fire him.

Mr. KAGHAN. If I found someone was putting Communist books on our shelves, I would fire him.

The CHAIRMAN. If you found the man who had been putting them on the shelves, previous to the Dulles order, would you fire him?

Mr. KAGHAN. Yes; I would have to take a look in the circumstances, sir. I could not fire anyone outright, without first inquiring why he did what he did and what the purpose was.

The ChaIRMAN. Mr. Reed Harris was quoted as saying the other day on a program that there were only 6 Communist books in the information libraries, and that those were there solely for the information officers. If he was correctly quoted, would you say that was a true statement, or a false statement?

Mr. KAGHAN. I am sorry, sir. Could I have the question repeated?

The CHAIRMAN. Mr. Reed Harris was quoted as saying that there were only 6 books in our information libraries by Communist authors, and that they were not there for the general public but merely for the information officers. Is that a correct statement?

Mr. KaGHAN. I couldn't judge that statement, sir.

The ChaIRMAN. You could not? Is that a correct statement of the facts? Mr. KAGHAN. I find it difficult to answer that, because I assume that all the books on the shelves of the American Houses are for the general public.

The ChaIRMAN. So that as far as you know, there were a sizable number of books by Communist authors on the general shelves for the general public?

Mr. Kaghan. No, sir; I do not know that there was a sizable number.

The Chairman. Well, you said the works of some dozen Communist authors were there.

Mr. KAGHAN. I said I though[t] that possibility by this time a dozen authors may have been removed. There may be fewer. I remember 4 or 5 that I heard about.

The Chairman. So you do know there were the works of at least 4 or 5 Communist authors on the book shelves available to the general public?

Mr. KAGHAN. Yes; I know that 4 or 5 authors were ordered removed from the shelves.

The Chairman. Let me ask you: Did you write a play, Beyond Exile?

Mr. KAGHAN. The name is familiar; yes.

The ChaIRMan. Does this play consist largely of a series of conversations between a father and son? 
Mr. KAGHAN. Sir, I don't remember what that play was about.

The ChaIRMan. Well, I will refresh your recollection, then, if I may. Here is one of the speeches made by the son to the father. And this consists largely of a running argument, the father trying to convince the son he should not be a Communist, the son trying to convince the father that he should be a Communist. Let us take the finale of this play. The son says:

Well, that's a fine how-do-you-do. It isn't enough that my father has to be a capitalist, but he's got to come out openly and betray his employees, just like all the other dirty capitalists. Do I have to come here and tell my own father that he is a slavedriver, an exploiter of labor, an enemy to civilization?

And the father, finally, in the close, has this to say. He says:

Peter, Peter, for God's sake listen to me, Peter. You were right, do you hear, you were right! I have been all wrong, Peter.

Would you say that that would make good anti-Communist propaganda? Mr. KAGHAN. No, sir. It sounds pretty corny, now.

The CHAIRMAN. Is it merely corny? Is not that the Communist Party line right down to the last period?

Mr. KAGHAN. One of those statements would be the Communist Party line, yes. One of the characters that said that, apparently-

The Chairman. What part of this would not be the Communist line? The son arguing with the father that he should be a Communist, pointing out that the father is a dirty capitalist, an exploiter of labor, and the father ending by saying: "You were right, do you hear, you were right! I have been all wrong, Peter."

Is that not Communist propaganda?

Mr. KAGHAN. That would be Communist propaganda if that is what the whole play ends up with and is about. I don't recall what the play is about.

The Chairman. Would you like to review that play and give us your view of it?

Mr. KAGHAN. If you wish; yes, sir.

The ChaIRMAn. Yes; I would like to have you do it.

I think this is what we will let you do. We will be going over your plays. Just so there will be no claim that we have taken the material out of context, I believe you should review these plays of yours and come back here tomorrow morning, and tell us which ones you consider are Communist-line plays and which ones are not; whether you think we have been unfair to you in reading the excerpts that we have.

Now let me ask you this question. If you today felt the same as you felt in 1939, would you think that you were a proper man to head this information program? 
Mr. KAGHAN. No, sir. ${ }^{299}$

Joe McCarthy's type of demagoguery and beating up of witnesses was arguably not on Congressional display again in such a public way with numerous media outlets until Hillary Clinton testified before the Benghazi Committee in 2015. ${ }^{300}$

William Dix, IFC Chairman, had already begun planning an off-the-record conference to bring attention to recent national attacks on the free-trade of ideas even before the IIA controversy began. ${ }^{301}$ The planning led to the Westchester Conference, ${ }^{302}$ where "twenty-five librarians, publishers, and citizens, 'representing the public interest," met on May 2 and 3, 1953, at the Westchester Country Club in Rye, New York. ${ }^{303}$ They met for the primary reason of giving guidance to librarians trying to defend their fundamental principles and possibly raise some much-needed publicity against the censorship forces. ${ }^{304}$ Over 3,300 librarians attended the conference. ${ }^{305}$ The conference resulted in the Freedom to Read statement. ${ }^{306}$

299. Overseas Libraries Hearing, supra note 275, at Part 3, 199-200.

300. John Dean, Will the Committee on Benghazi Find a Sense of Decency?, VERDICT (Oct. 30, 2015), https://verdict.justia.com/2015/10/30/will-the-committee-on-benghazi-find-a-sense-ofdecency [https://perma.cc/FBT4-VPDE].

301. Robbins, Overseas Libraries Controversy, supra note 42, at 30-31.

302. Westchester Conference of the American Library Association \& the American Book Publishers Council, The Freedom to Read, 47 ALA Bull., Nov. 1953, at 481, 481 [hereinafter Westchester Conference].

303. Robbins, Overseas Libraries Controversy, supra note 42, at 30-31.

304. Westchester Conference, supra note 302, at 481.

305. Robbins, Champions of a Cause, supra note 124, at 32.

306. The Freedom to Read Statement was amended four times since 1953. The current version states:

"1. It is in the public interest for publishers and librarians to make available the widest diversity of views and expressions, including those that are unorthodox, unpopular, or considered dangerous by the majority.

2. Publishers, librarians, and booksellers do not need to endorse every idea or presentation they make available. It would conflict with the public interest for them to establish their own political, moral, or aesthetic views as a standard for determining what should be published or circulated.

3. It is contrary to the public interest for publishers or librarians to bar access to writings on the basis of the personal history or political affiliations of the author.

4. There is no place in our society for efforts to coerce the taste of others, to confine adults to the reading matter deemed suitable for adolescents, or to inhibit the efforts of writers to achieve artistic expression.

5. It is not in the public interest to force a reader to accept the prejudgment of a label characterizing any expression or its author as subversive or dangerous.

6. It is the responsibility of publishers and librarians, as guardians of the people's freedom to read, to contest encroachments upon that freedom by individuals or groups seeking to impose their own standards or tastes upon the community at large; and by the government whenever it seeks to reduce or deny public access to public information. 
Dan Lacy had worked at the Library of Congress since 1952 and had been the previous director of the IIA's Information Centers Service, which ran the overseas libraries. ${ }^{307}$ While at the Library of Congress for only a month, Lacy received a call from the Acting Director, Richard Humphrey, telling him that McCarthy had asked him for a list of the collections making up the oversees libraries. ${ }^{308}$ In a short time, Lacy traded his Library of Congress position to head the American Book Publishers Council (ABPC) ${ }^{309} \mathrm{He}$ "believed that if McCarthy succeeded in his attacks on the overseas libraries, 'there was every reason to believe' that he would 'go after' domestic libraries." "'10

Lacy credited Douglas Black of Doubleday, a "blazing freedom of speech guy," for Eisenhower's interest in the Westchester Conference and what resulted in a significant letter. ${ }^{311}$ Black was the president of the ABPC at the time and had become a "close friend" of Eisenhower during his tenure as president at Columbia University. ${ }^{312}$ Robert Bingham Downs, President of the ALA, had received a letter from President Eisenhower in June 1953, ${ }^{313}$ which helped establish the press's interest in the Westchester Conference and, most specifically, in the Freedom to Read statement. ${ }^{314}$ The Overseas Library Statement also came from the Westchester Conference. ${ }^{315}$

In President Eisenhower's letter to Downs, he praised librarians for being preservers of freedom for the mind and decried those who believed that the devices of tyrants can serve freedom. ${ }^{316}$

The libraries of America are and must ever remain the homes of free, inquiring minds. To them, our citizens - of all ages and races, of all creeds and political persuasions - must be ever able to turn with clear

7. It is the responsibility of publishers and librarians to give full meaning to the freedom to read by providing books that enrich the quality and diversity of thought and expression. By the exercise of this affirmative responsibility, they can demonstrate that the answer to a 'bad' book is a good one, the answer to a 'bad' idea is a good one."

Am. Library Ass'n \& Ass'n Am. Publishers, The Freedom to Read Statement, http://www.ala. org/advocacy/intfreedom/freedomreadstatement (last updated June 30, 2004) [https://perma. cc/6G47-7GD5] (commentary following each proposition omitted).

307. Robbins, Overseas Libraries Controversy, supra note 42, at 28.

308. Id.

309. Id. at 30 .

310. Id.

311. Louise S. RobBins, CENSORShIP AND the AMERICAN Library: The AMERICAN Library Association's Response to Threats to Intellectual Freedom, 1939-1969, at 82 (1996)

[hereinafter Robbins, Censorship And the American Library].

312. Robbins, Overseas Libraries Controversy, supra note 42, at 33.

313. RobBins, CENSORship AND the AMERICAN Library, supra note 311, at 81.

314. Robbins, Overseas Libraries Controversy, supra note 42, at 33.

315. Id.

316. RoBBINS, CENSORSHIP AND THE AMERICAN LIBRARY, supra note 311, at 81. 
confidence that there they can freely seek the whole truth, unwarped by fashion and uncompromised by expediency. ${ }^{317}$

The Overseas Library Statement pronounced that the overseas libraries did not belong to a Congressional Committee or the State Department, but rather to the American people. ${ }^{318}$ The statement asserted of the overseas libraries:

[T] hey are among the most effective weapons possessed by the United States in the battle to preserve free men and free minds from the enslavement of Communist political and intellectual galanny. We know that their effectiveness has suspended on the conviction among foreign users that here was a free and open source of truth to which they could turn with confidence for information and enlightenment. ${ }^{319}$

"American Book Publishers Council [was] the [leading] trade group for the book publishing industry," 320 and Dan Lacy —its managing director-was the principal author of the statement. ${ }^{321}$ The statement praised President Eisenhower's recent "attack" on book burning ${ }^{322}$ (in his address to the Dartmouth Commencement inserted below). The statement also affirmed that the primary value of free libraries is to enlighten "enslaved minds abroad as at home." 323 The statement went on to state that the "integrity and effectiveness" of the mission required four things:

1. The libraries must express in themselves and their services the ideas of freedom for which they speak.

2. They must provide a service of uncompromising integrity. Their usefulness to the United States rests on the assurance of their users that they are places in which to learn the truth.

3. The Information Administration must be free to use in its libraries what books soever its responsible professional judgment determines are necessary or useful to the provision of such a service. To deny itself the tools it needs to serve the United States for irrelevant reasons of the past associations of authors and in fear of domestic criticism is indefensible.

4. Though no one could justify or would seek to justify the use of the overseas libraries to disseminate material harmful to the United

317. Id

318. Overseas Library Statement, 47 ALA Bull., Nov. 1953, at 487.

319. Id.

320. Francoeur, supra note 140, at 35; see also RoBBINS, CENSORSHIP AND THE AMERICAN LIBRARY, supra note 311, at 77.

321. Matthew T. Bolen, The American Library Association, US Government, and the Fight for Intellectual Freedom, 1939-1953, at 52 (Apr. 2006) (unpublished M.S. Master's Paper, University of North Carolina at Chapel Hill); RoBbins, CENSORSHIP AND THE AMERICAN LiBRARY, supra note 311, at 81 (Overseas Library statement was written "largely by Lacy").

322. Overseas Library Statement, supra note 318, at 487.

323. Id. 
States, it is unworkable to abandon the simple criterion of whether a book is useful to the purpose of the libraries and to substitute elaborate, irrelevant, and offensive schemes of "clearance" of authors. $^{324}$

President Eisenhower's pertinent remarks addressing the book burners were off the cuff at the Dartmouth commencement. He did not mention McCarthy, but the remarks appeared to be addressed to his rhetoric:

Don't join the book-burners. Don't think you are going to conceal faults by concealing evidence that they ever existed. Don't be afraid to go in your library and read every book, as long as that document does not offend our own ideas of decency. That should be the only censorship.

How will we defeat communism unless we know what it is, and what it teaches, and why does it have such an appeal for men, why are so many people swearing allegiance to it? It is almost a religion, albeit one of the nether regions.

And we have got to fight it with something better, not try to conceal the thinking of our own people. They are part of America. And even if they think ideas that are contrary to ours, their right to say them, their right to record them, and their right to have them at places where they are accessible to others is unquestioned, or it isn't America. ${ }^{325}$

McCarthy did not think the speech was for his benefit. ${ }^{326}$ However, many others thought differently. ${ }^{327}$ At his press conference the following week, in response to a question on the book-burner matter, Eisenhower said he never speaks of personalities. ${ }^{328}$ Three days after Dartmouth, Eisenhower said, "If the State Department is burning a book which is an open appeal to everybody in those foreign countries to be a Communist, then I would say that falls outside the limits I was speaking [of] and they can do as they please to get rid of them." ${ }^{329}$

324. Id.

325. Dwight D. Eisenhower, Remarks at the Dartmouth College Commencement Exercises, Hanover, New Hampshire (June 14, 1953), AM. PrESIDENCY PROJECT, https://www.presidency. ucsb.edu/node/231609 [https://perma.cc/W63A-EL8U].

326. Allen Yarnell, Eisenhower and McCarthy: An Appraisal of Presidential Strategy, 10 Presidential Stud. Q. 90, 93 (1980) (citing N.Y. Herald Trib., June 17, 1953, and N.Y. Daily News, June 17, 1953, Democratic National Committee Clipping File, Harry S. Truman Library).

327. Yarnell, supra note 326, at 93; see also id. at 97 n.26 ("For example, see Eric Sevaried's news analysis of June 15, 1953 in the Arnold Eric Sevaried Papers, Library of Congress.”).

328. Id. at 93; The President's News Conference of June 17, 1953, in Public PaPers of the Presidents of the United States: Dwight D. Eisenhower 426 (June 17, 1953) ("Now, Merriman, you have been around me long enough to know that I never talk personalities.”).

329. Tom Wicker, Dwight D. EISEnhower 59 (Arthur M. Schlesinger, Jr., ed., 2002). 
As the fruits from the Westchester Conference were resolved and published, things looked up for intellectual freedom. The President had sent a letter to the ALA praising librarians for fighting book-burning, and he said as much at the Dartmouth Commencement. The Overseas Library Statement adopted by the ALA Council and, in particular, the Freedom to Read statement, were getting significant attention primarily due to the President having spoken out against burning books and then his subsequent retreat. ${ }^{330}$

The New York Times publicized the Freedom to Read statement and stated it belonged among the essential American state papers. ${ }^{331}$ Several media outlets covered the statement favorably. ${ }^{332}$ In early July, the State Department ordered the reinstatement of all but twenty-five of the books earlier removed in the spring. ${ }^{333}$ McCarthy's attack on overseas libraries was done.

The Senate censured McCarthy on December 2, 1954, on a vote of 67 to 22, for failing to conform to its rules of comity and civility during the ArmyMcCarthy hearings. ${ }^{334}$ The hearings stated issues to investigate Roy Cohn's order, acting on McCarthy's behalf, to David Schine's Army commander telling him to give his recently drafted congressional aide preferential treatment. ${ }^{335}$ The real issue behind the ruse was for the Senate to bring McCarthy down. ${ }^{336}$

\section{CONCLUSION}

Can the politics of today replicate the early 1950s and its censorship effects on public libraries? Can a great catastrophe, such as the COVID-19 pandemic, create a similar scenario to the fallout of the Great Depression, creating a climate of fear, paranoia, and anger resulting in the censorship of so-called unpatriotic materials? This paper has addressed themes traditionally associated with a culture of censorship: the burning, banning, or preventing the publication of books ${ }^{337}$; the censoring and attempting to manipulate news outlets ${ }^{338}$; the warning of the dangers of indoctrinating children with poison ${ }^{339}$; the conforming to the paranoia

330. Robbins, Censorship AND the American Library, supra note 311, at 81.

331. Id. at 82 .

332. Id.

333. Strout, supra note 291, at 100.

334. The Censure Case of Joseph McCarthy of Wisconsin (1954), U.S. SEN., https://www. senate.gov/artandhistory/history/common/censure_cases/133Joseph_McCarthy.htm (last visited Oct. 31, 2020) [https://perma.cc/SY9K-8X23] (citing adaption from Anne M. Butler and Wendy Wolff, United States Senate Election, Expulsion, and Censure Cases, 1793-1990, S. Doc. No. 10333 (1995)).

335. Stone, supra note 5, at 1402 (citing Thomas C. Reeves, The Life and Times of JoE MCCARTHY: A BiogRAPHY 536-37 (1982)).

336. Id.

337. See supra notes 37-46, 213-31, 271-74, 290-94, 320-30 and accompanying text; see infra notes 359-61 and accompanying text.

338. See supra notes 153-57, 174-84 and accompanying text.

339. See supra notes 6-22, 31-36, 60-64, 153-62, 201-05 and accompanying text; see infra 
and fear associated with loyalty oaths ${ }^{340}$; and the attacks on governmentsponsored news and information sources, like the VOA, dedicated to providing its audience the truth on all matters. ${ }^{341}$

Former Executive Director of the ALA's Office for Intellectual Freedom and the Freedom to Read Foundation James LaRue ${ }^{342}$ has stated that with "the Trump administration's attempts to order media blackouts of federal agencies, it's important that we resist any attempt to use the power of government to stifle the very agencies charged, like libraries, with the dissemination of information."'343

One way in which public libraries fought back against Trump is making their venues sanctuaries for immigrants. ${ }^{344}$ Many libraries are attempting to guide readers to trustworthy information sources. ${ }^{345}$ According to the Institute of Museum and Library Services (IMLS), new Americans are significant users of public libraries. ${ }^{346}$ Elizabeth McKinstry, a public librarian in Dedham, Massachusetts, stated, "We are huge resources for newcomers to this country, whether it's for connection to this country, legal resources, testing preparation, citizen tests, services like storytimes or homework help." ${ }^{\text {347 }}$

In response, President Trump seemingly attempted to limit the free flow of information. In his preliminary 2018 budget proposal, Trump tried to eliminate the IMLS. ${ }^{348} \mathrm{He}$ proposed to keep only ten percent of the IMLS budget, enough to shut its doors. ${ }^{349}$ IMLS helps fund 123,000 libraries and 35,000 museums on only $.05 \%$ of the federal budget, or just $\$ 230$ million. ${ }^{350}$ The library community

notes 381-83 and accompanying text.

340. See supra notes 91-101, 133-37 and accompanying text.

341. See supra notes 227-54 and accompanying text.

342. About me, JAMES LARUE, https://www.jlarue.com/about-me (last visited Jan. 10, 2021) [https://perma.cc/HT57-RMQB].

343. James LaRue, OIF Condemns Government Agency Censorship, AM. LiBR. Ass'N: INTELL. FreEdom Blog (Jan. 25, 2017), https:/www.oif.ala.org/oif/?p=8410 [https://perma.cc/D6KCV6QD].

344. Danuta Kean, US Libraries Join Struggle to Resist the Trump Administration, GUARDIAN, (Feb. 21, 2017, 9:45 AM), https://www.theguardian.com/books/2017/feb/21/us-libraries-joinstruggle-to-resist-the-trump-administration [https://perma.cc/M8BH-LUJA].

345. Id.

346. Elizabeth Flock, Why These Librarians are Protesting Trump's Executive Orders, PBS NewsHour (Feb. 13, 2017, 2:27 PM), https://www.pbs.org/newshour/arts/librarians-protestingtrumps-executive-orders [https://perma.cc/SD3V-AM5D] ("55 percent of new Americans use a library at least once a week.").

347. Id.

348. Matthew Perry, President's Budget Includes Elimination of Institute of Museum and Library Services, MAss. BoARd LiBr. COMMissioners (Mar. 17, 2017), https://mblc.state. ma.us/news/news-releases/2017/nr170317.php [https://perma.cc/Y8ML-2KFG].

349. Lisa Peet, Federal Budget Compromise Keeps-and Boosts-IMLS Funding, LiBR. J. (Mar. 26, 2018), https://www.libraryjournal.com/?detailStory=federal-budget-compromise-keepsand-boosts-imls-funding [https://perma.cc/PFR2-4JVQ].

350. Akunna Eneh, Trump Takes Aim at Libraries, TRUThout (Apr. 26, 2017), 
countered Trump's bid to eliminate the IMLS through advocacy. ${ }^{351}$ On May 1, 2018, Congress listened and revealed a bipartisan compromise that preserved the IMLS and added one million dollars to the agency's funding. ${ }^{352}$

The setback for Trump did not deter him. With his 2021 "A Budget for America's Future" totaling $\$ 4.875$ trillion, Trump tried for the fourth straight year to eliminate the IMLS. ${ }^{353}$ On February 10, 2020, Trump requested $\$ 23$ million to close the IMLS by October 1, 2020..$^{354}$

Trump learned well the teachings of McCarthy's playbook about how to subvert groups of people and American outlets of free information. Roy Cohn, the ruthless chief counselor for McCarthy's Senate hearings, was later Trump's lawyer, mentor, and tutor. ${ }^{355}$ Another significant danger to the free flow of information is COVID-19, a catastrophic event with points of comparison to the Great Depression. ${ }^{356}$ One of the noteworthy contributors to the development of autocratic governments in the 1930s was the economic catastrophe leading to world depression. ${ }^{357}$ Nazism and fascism led to leaders who banished the free flow of ideas and also led to the burning of books. ${ }^{358}$

Beginning on May 10, 1933, student groups from thirty-four university towns and cities looted libraries and bookstores and burned books they claimed were "un-German." 359 The symbolic act on May 10th resulted in approximately 25,000 burned books. ${ }^{360}$ Some book burning took place days later, delayed by rainy

https:/truthout.org/articles/trump-takes-aim-at-libraries/ [https://perma.cc/U8F4-KGHL].

351. Id.

352. Peet, supra note 349.

353. Andrew Albanese, In 2021 Budget Proposal, Trump Once Again Seeks to End Federal Library Funding, PuBlishers WKLY. (Feb. 11, 2020), https://www.publishersweekly.com/pw/bytopic/industry-news/libraries/article/82390-in-2021-budget-proposal-trump-once-again-seeks-toend-federal-library-funding.html [https://perma.cc/CU3N-WLDT].

354. IMLS Statement on the President's FY 2021 Budget Proposal, Inst. Museum \& LiBR. SERVS. (Feb. 10, 2020), https:/www.imls.gov/news/imls-statement-presidents-fy-2021-budgetproposal [https://perma.cc/J2MK-AAP4].

355. Marie Brenner, How Donald Trump and Roy Cohn's Ruthless Symbiosis Changed America, VANITY FAIR (June 28, 2017), https://www.vanityfair.com/news/2017/06/donald-trumproy-cohn-relationship [https://perma.cc/JZV6-SN27].

356. Peter Cohan, How COVID-19 Crunch Compares to Spanish Flu, Great Depression, ForBes (Apr. 6, 2020, 9:23 AM), https://www.forbes.com/sites/petercohan/2020/04/06/how-covid19-crunch-compares-to-spanish-flu-great-depression/\#4bfcd5a01798 [https://perma.cc/3 WE2TEDS].

357. Id.

358. U.S. Holocaust Mem'l Museum, Book Burning, Holocaust EnCYCLOPEDIA, https:// encyclopedia.ushmm.org/content/en/article/book-burning (last visited Oct. 31, 2020) [https://perma. cc/K3KG-83MZ] [hereinafter Book Burning].

359. Id.

360. Id. 
weather. Others held book-burning events on June 21 st, the summer solstice, a traditional bonfire day in Germany. ${ }^{361}$

The Great Depression did not occur as an unforeseen pandemic like COVID19 but rather as a cluster of factors leading to an endemic affecting the world's economies. The factors included "World War I, changing American ideas of debt and consumption, and an unregulated stock market." ${ }^{362}$ These factors led to a perfect stew of worldwide economic chaos. ${ }^{363}$ "Deteriorating economic conditions in Germany in the 1930s created an angry, frightened, and financially struggling populace open to more extreme political systems, including fascism and communism." 364

With COVID-19 uncontrolled for a year or longer, what are the chances that another worldwide depression with financial catastrophe and concomitant fear and anger occurs? At the time of the Great Depression, there was no strong world leader to provide adequate solutions. ${ }^{365}$ The United States, United Kingdom, France, and others might have formed a cooperation to salvage the world economy. ${ }^{366}$ However, there was not a great world leader amongst them to initiate such an effort. ${ }^{367}$ Instead, the leaders in the various countries focused primarily on their own domestic struggles during the depression. ${ }^{368}$

Without influential world leaders and a successful League of Nations to maintain world peace, there was a definite leadership void in the 1930s. ${ }^{369}$ An ultra-Nationalist leader such as Adolph Hitler came to power to fill the void in unifying the patchwork Germany states into one ultra-nationalist country. ${ }^{370}$ After less than nine months in office, Hitler asked for "equality of status," which would allow Germany to up its military level to the other major powers in the League of Nations. ${ }^{371}$ Germany entered into the League of Nations in 1926 after it had

361. Id.

362. U.S. Holocaust Mem'l Museum, The Great Depression, Holocaust Encyclopedia, https://encyclopedia.ushmm.org/content/en/article/the-great-depression (last visited Oct. 31, 2020) [https://perma.cc/7F9D-N8XC].

363. Id.

364. Id.

365. Jeffrey D. Sachs, COVID-19 and Multilateralism, Horizons: J. InT'L REL. \& Sustainable DeV., Spring 2020, at 30, 30.

366. Id. at 31 .

367. Id. at 30-31.

368. Id. at 31 .

369. The United Nations suffered repeated defeats in the 1930s, including losing Germany when Hitler pulled out in 1934 and an incapability to stop the militarization of the Rhineland in 1936. Qizhi He, The Crucial Role of the United Nations in Maintaining International Peace and Security, in 23 Kluwer Law Int'L, The United Nations at Age Fifty: A Legal Perspective 77 (Christian Tomuschat ed., 1995).

370. Book Burning, supra note 358.

371. A. J. Nicholls, Weimar AND the Rise of Hitler 48 (Geoffrey Warner ed., 3d ed. 1991). 
proven itself as a peaceable nation. ${ }^{372}$ The League refused Hitler's request, so he announced Germany's withdrawal from the World Disarmament Conference..$^{373}$

Unlike world leaders not working together during the Great Depression, there has been cooperation amongst several countries in response to COVID-19. ${ }^{374}$ World leaders organized an online conference on May 4, 2020, bringing together the European Union and non-EU countries like Britain, Japan, Saudi Arabia, Canada, Norway, and South Africa. ${ }^{375}$ In just a few hours, the countries collectively raised 7.4 billion euros ( $\$ 8.1$ billion), kick-starting "unprecedented global cooperation," stated the head of the European Commission, Ursula von der Leyen. ${ }^{376}$

The director-general of the World Health Organization (WHO) addressed the online conference educating the countries on how it is handling the pandemic. ${ }^{377}$ Donald Trump did not join the world leaders representing the United States. ${ }^{378}$ On April 14, 2020, President Trump, facing significant criticism for his response to the pandemic, attempted to shift the blame to the WHO and ordered his administration to halt funding to the organization. ${ }^{379}$ Trump asserted that the WHO made a series of "devastating mistakes" in battling the pandemic. ${ }^{380}$

While Donald Trump is no Adolph Hitler, there are similarities relating to the freedom of expression. It was May 10, 1933, when the Nazi youth attacked libraries and bookstores collecting books to burn. ${ }^{381}$ It was May 28, 2020, when Trump, by executive order, escalated conflict with Twitter and other tech giants by rolling back liability protections under section 230 of the Communications

372. Sen. Hubert H. Humphrey, Control and Reduction of Armaments:Final Report of the Committee on Foreign Relations Subcommittee on Disarmament, S. Rep. No. 2501, at 225 n.3 (1958), https://play.google.com/books/reader?id=pBNQAQAAMAAJ\&amp;hl=e\&pg= GBS.PA225.

373. Harold A. Peters, Germany Withdraws from League of Nations, Disarmament Pact, UPI ARCHIVES (Oct. 14, 1933), https://www.upi.com/Archives/1933/10/14/Germany-withdraws-fromLeague-of-Nations-disarmament-pact/5411430087122/ [https://perma.cc/VUU6-82AX].

374. Robin Emmott \& Francesco Guarascio, World Leaders Pledge \$8 Billion to Fight COVID-19, WORLD ECON. F. (May 5, 2020), https://www.weforum.org/agenda/2020/05/worldleaders-covid-19/ [https://perma.cc/BC4Y-FFVE].

375. Id.

376. Id.

377. Id.

378. Id.

379. Michael D. Shear \& Donald G. McNeil Jr., Criticized for Pandemic Response, Trump Tries Shifting Blame to the W.H.O., N.Y. Times (Apr. 14, 2020), https:/www.nytimes.com/ 2020/04/14/us/politics/coronavirus-trump-who-funding.html [https://perma.cc/CA92-ZHTQ].

380. Id. Essentially Trump was trying to place the mistakes he had made on the WHO.

381. Book Burning, supra note 358. 
Decency Act of $1996 .^{382}$ Trump ironically claimed he was protecting free speech by reigning in tech giants such as Twitter, Facebook, and Google. ${ }^{383}$

In reality, the tech giants were fact-checking Donald Trump's statements on social media because they have a responsibility to fact check all politicians and other noteworthy leaders for truth without bias. ${ }^{384}$ Trump was attempting to transform tech giant platforms into publishers who can then be liable for the content. ${ }^{385}$ Trump was hoping that the "great attorney general" would look at the Tech Giants as the EU does, suing them and collecting fines. ${ }^{386}$ It creates a stealthy denial of human rights that contravenes the Constitution. ${ }^{387}$ Regulating tech companies violates the First Amendment, which protects free speech.

Although there was no Internet when Hitler ruled Germany, Trump's attacks on freedom of expression in the Internet age may have impressed the Fuhrer. Where will public libraries be in five to ten years? Will the effects of a political climate and a catastrophe still affect the freedom of expression? As time goes by, political climates change with the times. Throughout time immemorial, there have been people who think that people not like us are to be distrusted, not taken seriously, less than equal, punished, or even harmed. If opportunistic leaders like Trump, McCarthy, or Hitler supply fear and anger to the equation, there is a true danger to our freedoms. Notorious events happen leading to unrest, such as the Great Depression creating an opportunity for Hitler, the Cold War for McCarthy,

382. Brent Kendall \& John D. McKinnon, Justice Department Proposes Limiting Internet Companies' Protections, WALL ST. J., https://www.wsj.com/articles/justice-department-to-proposelimiting-internet-firms-protections-11592391602 (last updated June 17, 2020, 5:01 PM) [https:// perma.cc/7P5M-2Y83].

383. Maggie Haberman \& Kate Conger, Trump Signs Executive Order on Social Media, Claiming to Protect 'Free Speech', N.Y. TIMES, https://www.nytimes.com/2020/05/28/us/politics/ trump-order-social-media.html (last updated June 2, 2020) [https://perma.cc/4ABX-PUQF].

384. Elizabeth Dwoskin, Twitter's Decision to Label Trump's Tweets Was Two Years in the Making, WASH. Post (May 29, 2020, 7:55 PM), https:/www.washingtonpost.com/technology/ 2020/05/29/inside-twitter-trump-label/ [https://perma.cc/WWJ8-M3U8].

385. See Clara Hendrickson \& William A. Galston, Big Tech Threats: Making Sense of the Backlash Against Online Platforms, BRookINGS (May 28, 2019), https://www.brookings.edu/ research/big-tech-threats-making-sense-of-the-backlash-against-online-platforms/ [https://perma.cc/572B-JRCX].

386. Kate Rooney, Trump Likes EU Fines Against Big US Tech Companies and Would Like Some of That Money, Too, CNBC (June 10, 2019), https://www.cnbc.com/2019/06/10/trump-likesthat-the-eu-fines-big-us-tech-companies-and-would-like-some-of-that-money-too.html [https://perma.cc/VZ9W-SS2S].

387. Jennifer Huddleston, Content Moderation, Section 230, and The First Amendment, AM. ACTION F. (May 28, 2020), https:/www.americanactionforum.org/insight/content-moderationsection-230-and-the-first-amendment/ [https://perma.cc/UD86-RP2U]. 
and the Tea Party, with "its anti-institutionalism and breaking of norms," for Trump. ${ }^{388}$ It is up to the people ultimately. Will they be influenced and react with fear, paranoia, and anger? Or, as Justice Brandeis stated, will they combat fears that led men to burn women by allowing speech concerning witches and witchhunting full and uncensored consideration?

388. Geoffrey Kabaservice, The Forever Grievance, WASH. Post (Dec. 4, 2020), https://www. washingtonpost.com/outlook/2020/12/04/tea-party-trumpism-conservatives-populism/ [https://perma.cc/CS4M-2SUP]. 